Portland State University

PDXScholar

$11-20-2020$

\title{
Six Feet of Distance Between Belonging: Expansions and Maintenance of Citizenship During COVID-19
}

Johnathon Daniel Vargas

Portland State University

Follow this and additional works at: https://pdxscholar.library.pdx.edu/honorstheses

Part of the International and Area Studies Commons

Let us know how access to this document benefits you.

\section{Recommended Citation}

Vargas, Johnathon Daniel, "Six Feet of Distance Between Belonging: Expansions and Maintenance of Citizenship During COVID-19" (2020). University Honors Theses. Paper 975.

https://doi.org/10.15760/honors.999

This Thesis is brought to you for free and open access. It has been accepted for inclusion in University Honors Theses by an authorized administrator of PDXScholar. Please contact us if we can make this document more accessible: pdxscholar@pdx.edu. 
Six Feet of Distance Between Belonging: Expansions and Maintenance of Citizenship During

COVID-19

By

Johnathon Vargas

An undergraduate honors thesis submitted in partial fulfillment of the requirements for the

degree of

Bachelor of Arts

in

University Honors

and

International and Global Studies (Development)

Thesis Advisor:

Dr. Priya Kapoor

Portland State University 2020 


\begin{abstract}
Citizenship is the dominant 'political regime of belonging' that is coupled with rights and access to necessary material resources. This paper reviews the dimensions of citizenship, its connection to the nation-state, and analytical approaches to belonging. The review of literature is then applied to an analysis of how COVID-19 has challenged notions of citizenship by revealing maintenance strategies and enactments of belonging in Portland, Oregon and the surrounding region. This paper uses qualitative research to analyze events, communication, activities, and conditions of those who lack citizenship, mediated through local media. Data collected from the first 3 months of the COVID-19 pandemic is translated into themes to reveal expansions of citizenship and instruments to legitimize social and physical bordering processes.
\end{abstract}


Six Foot Distance Between Belonging: Expansions and Maintenances of Citizenship During COVID-19

\section{Introduction}

My initial project was to be about borders, and their ambiguous realities in the material and imaginative realms of the city/nation-state. I had intended to map out social/material borders - active sites of contestation of belonging to space, social spheres, marketplace, and political engagement. This inquiry derived from a personal feeling of some thing, that governs urban space and the community of Portland along social and spatial locations. I figured that these structures are defended, borderized, and created to ensure feedback loops of a referent-we and the 'other'. One day I walked into the Portland Mercado for the first time, and something caught my interest. Now I have been in many similar latinx spaces here in Oregon, but what was different in this case was the historical and statistical material they had on the walls. It depicted latinx history in Oregon, their contributions and existence on this land. And then I stumbled across a graph that showed the percentage of Latinx living in the tri-met area. I was astounded, some areas in the urban periphery were nearly 50\% latinx. Even so, it didn't seem real to me. I grew up in Eugene, and my family and I felt like our complete selves were different, and not fully belonging. We had to hide part of ourselves - my parents did not speak Spanish directly to me in an effort to make sure I did not develop any accent, that otherwise would otherize me. Perhaps, because the status-quo, the citizen, the people deemed to belong to the community, did not speak Spanish. 
In the Portland Mercado, a graph hangs on the wall that labels the demographics of metropolitan locations. It showed a strong percentage of people like me lived and belonged to such communities in Oregon. But, Portland continued to be highly undiversified. Upon further inspection subaltern communities - immigrants, refugees, people of color, in general are settled in the urban periphery - their homes, businesses, even work. Now some-thing bugged me about this, and made me question, what processes and social management is working toward to sustain this being?

When I looked at the map in the Portland Mercado, I saw a border. One recognizable by what Portland was composed of, and equally what it wasn't. Borders are a process of social division, something that is not strictly territorial, juridical, political, or an economic phenomenon. Thomas Nail states it is just as apolitical, aterritorial, and ajuridical. What may be a border for some, is a bridge for others (Nail, 2016, p. 3). But either outcome results in mereley the license to move and exist across space based upon identifiable criteria. Understanding this unravels the connection between mobility and identity in material and imaginative spaces that our constructed borders enforce and seperate. Borders are a demarcated site that allows certain individuals, discourse, ideas, and things to pass through or circulate back (Nail, 2016, p. 29). This process happens on both sides of the border and defines both its inclusionary, exclusionary, ambivalent nature.

My problem with borders, both in the physical and imaginative sense, is that it denies our fellow human beings a seat at the table, due to the innate humannes of mobility. I believe access to rights and the ability to voice our own experiences, obligations, entitlements, and desires for the future should not be paired with our location of origin. Achille Mbembe, Cameroonian 
philosopher and political theorist writes, "becoming-human-in-the-world is a question neither of birth nor of origin; it is a matter of journeying, of movement, and of transfiguration" (2019, p. 187). But in our times, movement of human beings in the physical and imaginative sense is highly guarded and contextually based. Many often face borders, intended to keep out or annihilate the imagined "enemy" of the state, others may enjoy more freedom. It's been the discourse for as long as I can remember. As much as I wanted to, at the time, turn my project into something that would produce material evidence of borders through mapping space and personally engaged discourse; COVID-19 and the events that followed changed things, both materially and imaginatively, a feeling not solely experienced by me but all of us.

This thing I referenced earlier, is concerned with distinguishing which bodies, politically, socially, and legally belong to a given space. In the age of the modern city and nation state, citizenship is the mere-license to belong to a shared space; and it has and continues to be socially produced and contested (Eudell, 2015, p. 245). Adrian Favell defined the politics of belonging (the legal, political, and social codes of citizenship) as being "the dirty work of boundary maintenance" (Yuval-Davis, 2007, p. 563). Before anything becomes materialized, it must be imagined in our own psyche and then practiced. The idea of citizenship: the license for the recognition of a human bearing rights to exist in a particular space, is the foreground of the construction of many borders in this world. In an effort to even begin to fully recognize the borders around us, and create a more inclusive space, we must interrogate the inner workings of our psyche that imagine and take autopoietic form by turning into physical actions and thus reaffirm our constructed narratives. 
This notion of borders being constituted of material and imaginative spaces, where division and new processes of becoming occurs; is explored in Chicana poet, writer, and feminist thoerist, Gloria Anzuldula's semi-autobigraphical work, Borderlands/La Frontera: The New Mestiza. In this foundational work on chicanx identity and the workings of bordering processes Anzuldula writes, "the struggle has always been inner and is played out on the outer terrains" (1987, p. 109). A common phrase in border studies is "borders are everywhere", meaning that they exist at the periphery and within our conceptualized space. But the act of conceptualizing such space, self, and other in which the border distinguishes, must be analyzed and critiqued. Within such analysis, we can gather evidence of a particularistic sense of we that attributes to the functioning of an autochthonous lens through which we see the world. These current strategies of representation and belonging, such as citizenship, create partial understandings of ourselves and others if we only analyze it at its face value.

If I am to seriously concern myself with man-made borders in the city, state, and the world, that includes/excludes residents from certain 'shared' space, rights, and resources; the idea and praxis of citizenship must be brought into consideration. Packed within such a concept is merely a license to recognize who our co-specifics are and just as importantly who we are and can be. I believe to properly address the issues we currently face, that is, kids, women, and men in cages - illegal 'essential workers' - disproportionate exposures to a deadly virus impoverished populations with no relief; interconnected problems, require both a global and local respatialized and reoriented understanding of ourselves. This means grappling with 'othering' processes that result in physical and imaginative divides that are borne out of the auto-instituting ideologies of the incommensurability of humans through ideas of race, gender, 
and the enforcing nature of the nation-state (Sharma, 2015, p. 177). These processes hide our human link and the attachments we create through everyday activities that produce new belongings.

The spread and impact of COVID-19 and Black Lives Matter this year has been experienced across the globe, and is a monumental event of our time that has forced us to reconsider our relations to each other. It has caused myself, people around me, local and global discourse, to consider the importance of a community with obligation to one another. As well as the pitfalls (mildly put) of the current structuring of belonging and allocation of resources based on conceptualization of who deserves to become, rather than being, a democratic, interconnected, community.

\section{Literature Review}

Why does citizenship matter? Thinking about my relationship to my own citizenship status, it has always been grounded in a sense of belonging, to each other's actions, to discourse over shared goals, and to the results of decisions made by those with power. And because of this relationship, we are propelled to represent our voice and ensure actions are made to benefit each other. But is this reality, this relationship to each other, solely centered around those who hold the legal status of citizenship? Others are equally affected by the political, the body that we are given license to partake, merely due to some form of derivative status. In recent years there have been a number of theoretical debates on how to approach citizenship, our understanding of it in relation to the nation-state, and to analyze its changing features (Yuval-Davis, 2006, p. 205). Bridging from the most common conceptions such as liberal, republic and communitarian theories of citizenship, notions of cultural and transnational citizenship have been developed to 
address inherent exclusionary tendencies of the former conceptions (Bloemrad et al., 2008). Such work pays attention to the "translation" or becoming of citizens through political and social landscapes that contest dominant discursive and institutional practices (Balibar, 2010; Youkhana, 2015, p. 14).

Citizenship has and often is used synonymously, or associated with belonging (Youkana, 2015, p. 12). Belonging is an important theoretical concept that will guide the framework of this thesis, an understanding of citizenship, and how individuals and groups create and contest "regimes of belonging" ( Stoke-Dupass, 2016, p. 139); the latter referring to where sense of place-belongingness come to fruition in social, cultural, territorial boundaries, and the allocation of rights and materials through the nation-state. Niral Yuval Davis, a professor emerita who has made important contributions to the understanding of belonging, and differentiates three major analytical categories to better understand the concept.

First being, social locations - a reference to the variety of axes of power such as gender, race, class, nation, profession, and stage of life cycle. (Yuval-Davis, 2006, p. 200). These social locations are never constructed among only one of these axes of power, but are multidimensional. The second category is identification and emotional attachments. Identities, formed individually and collectively, are narratives people construct for themselves and others to signify who they are and who they are not. These narratives are fluid, bound to shifts by contestations and changing conditions. They are also reflective of emotional investments and desire for attachments" (Yuval-Davis, 2006, p. 202). These investments and desire for belonging to regimes like nation-state citizenship, become more central the more threatened and secure individuals and collectives may feel. The third analytical category is shared ethical and political 
values. The space where social locations and identities and desire for attachment is valued and judged. Through rhetoric about how boundaries of belonging (i.e. citizenship) is and should be mapped, the politics of belonging come into play.

\subsection{Citizenship}

The most influential political project of belonging is the nation-state, to which citizenship becomes a dominant mode of discussing and analyzing groups' shared connection and responsibilities to one another. Citizenship, both in modern day and its antiquity, have been granted to subjects based on particularistic dimensions of being; which are regarded as the qualities that make people deserving of human rights and capable of meeting civic obligations. Likewise, citizenship has been instituted and acted out in bounded physical and social spaces. In it's western conception, the Greek city-state, it was deemed that men of leisure ascribed to their inner political animal, but only through participation in the polis (Heater, 2004, p. 17; Berlant, 2007. p. 9). Within the classical Greek notion, boundaries of citizenship were also demarcated within a specific territory, the polis (city). Scholars have attributed this practice as a "founding moment in the conceptualization of social relation in spatial-geometric terms" (Painter and Philo, 1995, p. 110); to which citizenship is 'mapped' onto space in both the physical and imaginative sense. Within this classical construction, citizenship of the Greek city-state rested on a particularistic sense of man, one that had a 'correct' baggage of lineage and virtues tied to a connection of land (Painter and Philo, 1995, p. 113). This land was worked on by those without the status of belonging - who's hierarchical existence secured leisure for deemed eligible citizens. Citizenship today functions in a similar pattern, and the effects of COVID-19 has again 
exposed the hierarchical, particular jus sanguinis, structures that inform who is afforded justice, opportunity, and safety - on the backs of the oppressed and exploited. The many who occupy the "essential work" but are still otherized, and are deemed to be shut out from rights and access that their co-habitants enjoy.

\subsection{The Nation-State}

The source of citizenship through the Greek city-state as a frame of reference may not resonate enough with our modern scene. Within a western knowledge system, traveling through the roman republic, the middle ages, and the renaissance - we meet our modern conception of citizenship, generally said to be imagined during the 18th century's democratic revolutions (Berlant, 2007, p. 37) . Which resulted in the first models of the nation-state, to which our current citizenship, in its formal sense, is attached to. As explained in Benedict Anderson's work, Imagined Communities, the successful national movements in the Americas, and shortly thereafter Europe and the World -ushered in a new understanding of political communities. Anderson's understanding offers the perspective that the nation-state system owes its conception to two centuries of transformation, to which imagined communities grew out of capitalizing on vernacular language (Anderson, 2006, p.44). Through capitalist mechanical reproduction, an imagined community (the nation-state) could be propagated to the illiterate and the literate masses within and outside of its locality. From Anderson's perspective, this resulted in a transmission of new political doctrines, or "piracy" of nationalist thought and identities. Through these conditions, "the 'nation' provided an invention on which it was impossible to secure a patent" (Anderson, 2006, p. 67). 
Now the nation-state as a near homogenous invention across the world, territorial and membership organizations - identity and sovereignty became tools for the monopoly of movement. This was done through a process of census, map, and museum, in which states imagined "their dominion, the nature of human beings it ruled, the geography of its domain, and the legitimacy of its ancestry" (Anderson, 2006, p. 163). Such a conception leads to sovereignty as the power to decide "who matters and who doesn't, who is disposable and who is not" (Mbembe, 2019, p. 80). In order to ensure a monopolization of the means of movement, people are sorted into varying categories between those who belong and do not on a vertical scale; 'citizen' and 'non citizen', 'skilled migrant', 'temporary worker', 'permanent resident', 'refugee', 'asylum seeker', and the 'illegal alien'. These categories have only become more naturalized and sanctified in a world that has been constantly intertwining and also balkanizing by codes and documented statuses such as passports, visas, and certificates that merely licenses one to be recognized by the community in a formal sense (Torpey, 200, p.9). Alas, territorial \& imaginative borders which seemingly are about the physical separation between nations, is also to the same degree about the separation of those within the same space (Sharma, 2015, pg 176).

This process is evident in the sub-categories of human groups that encompass citizenship discourse. Such an array of terms is a breadcrumb trail to the faultiness of citizenship's effort to even create a robust sense of belonging along paticularstic claims to those who hold such a status. The United States has and continues to witness this reality, wherein 'other' kinds of citizenship is fostered, "giving group members a series of spaces in which they can enjoy something like citizenship status as themselves and not as some distorted version of themselves" which the latter particularistic status engenders (Painter and Philo, 117). The underlying truth 
here is regardless of their status, these groups occupy the same space but are barred from full access to resources, power and security, based upon belonging understood through citizenship.

\subsection{Legal Dimension of Citizenship}

Citizenship has largely been understood and enacted in three dimensions: legal (rights), political (participation), and the social (belonging). The legal conception of citizenship is used in the sense of some way factually stating and then enforcing the boundaries and being of citizens. It is also within this dimension that the "other" are stated as illegal for the mistake of moving (Bloemraad et al., 2008, p.156). Within both cases, and all three dimensions, the framework to discuss, value, treat, and accept other humans are dictated and contested. In the case of our modern global nation-state system, citizens, more or less, are recognized to hold certain rights that are protected by the state according to the written and informal laws. Dominant in much citizenship theory is a liberal perspective, which emphasizes the social contract between both the state and citizen. This contract consists of both actors holding certain rights and obligations. These are commonly are recognized as paying taxes through work and/or property ownership, and until recently the gendered demand of "readiness to sacrifice one's life_—and to kill others - for the sake of the political community" (Yuval, Davis, 2006, p. 208); and the state's responsibility of protecting the citizen's rights endowed by the law (Bloemraad et al., 2008, p. 156).

The legal dimension of citizenship is one part of a matrix of belonging and subjection to removal. In this dimension a person's proximity to a "legal" or an illegal status in a given territory is determined and thus indexes one's allotted treatment as human induced with the full 
rights embodied by the laws of the nation-state. The citizenship status can be a derivative of one's place of birth (jus solis) or family (jus sanguinis). Those accidently born elsewhere, citizenship is acquired through naturalization - dictated by the norms and requirements of the ruling body.

In this dimension it is important to consider how laws and policies of citizenship are applied to various groups both in past and present practices that shape future outcomes. For example - Kristin A. Collins, a professor of law, unpacks the relationship between the history of jus sanguinis citizenship and laws governing marriage and birth status in the United States. In coalition with other dimensions of citizenship, jus sanguinis legal rulings served to exclude particular groups of people around a constellation of attitudes toward gender, sexuality, and race. Collins' work explores the history of racially nativist policies that were central to American nationality and gender-based family laws that have and continue to appear as "both natural and race neutral in the lines it drew between citizen and non-citizen" (Collins, 2014, p. 2143). Which continue to determine the citizenship status of individuals living today and will have intergenerational effects into the foreseeable future.

Like the dimensions of citizenship, axes of power like race, class, gender, sexuality, and nationality work together "as sites of domination and as potential sites of resistance"/expansion, in what Patricia Hill Collins calls a "matrix of domination" (Collins, 1990, 230, 227). Regarding the laws of citizenship and the rights afforded in the United States, enactments and understanding of such has been exclusionary based upon race and gender. The dispossession of indigenous land preceded by a slavery-democracy, the identity of U.S. citizenship has always been both inclusionary and exclusionary. The law that had set the first uniformed rules of 
citizenship was the Naturalization Act of 1790, which afforded citizenship to all "free white persons". This beginning piece excluded non-whites, white indentured servants, women, etc. Meaning that the first initial conception of the American citizen, legally speaking, was a white male property owner. Thus, in the U.S., all expansions of legal citizenship structure and understanding moves from this core understanding.

Josue Cisneros book, The Border Crossed Us, Cisneros explores this dynamic and its inherent exclusionary value toward racialized and ethnicized others via the California Constitutional Convention of 1849. After the Treaty of Guadalupe, Mexican-Californios negotiated the borders of their new found US citizenship, "that both resisted and reified coloniality and it's racialized/gendered dimensions" (Cisneros, 2014, p. 22). In rhetorical discourse Californios who had elite status through their families' economic power and their status as "gente de razón” (a reference proximity of white political performances), both enacted an expansion of citizenship and continued marginalization of mestizo, native indio, and black people. Californio delegate Pablo Noriego de la Guerra, at the 1849 California Constitution Convention, addressing the U.S. law on citizenship being held for white males stated:

Many citizens of California have received from nature a very dark skin; nevertheless, there are among them men who have heretofore been allowed to vote, and not only that, but to fill the highest public offices. It would be very unjust to deprive them of the privileges of citizens merely because nature had not made them 
white. But if, by the word "white," it was intended to exclude the African race, then it was correct and satisfactory. (Cisneros, 2014, p. 35)

Guerra would go on to sue the state of California for infringing on his rights as a white male, citizen. This rhetorical display presented two points, one being that the access of citizenship was thought to be had by proximity to a specific identity and performances - as stated legally by US law. Secondly, as a mestizo himself and those he represented, the rhetoric both enacted and contested US citizenship. Performing political rhetoric enacted a space of citizenship, and contested US citizenship through emphasis of mixed and native Mexican experiences of citizenship under the rule of the Mexican government. This display of political appropriation that Californios used to cultivate new identities and rights in regards to US citizenship reveals the constraints legal dimensions hold, and the way it also can be challenged.

\subsection{Political Dimension of Citizenship}

In theory those with the correct legal status may participate and be represented in political bodies to the full extent; and those without status may appropriate space through rhetoric and material performances. This dimension is part of the arena of the politics of belonging. Through the rights afforded to and protected by the state; political citizenship can be enacted through voting, running for elected office, protesting freely, etc. Regarding this research, politically and socially, boundaries of citizenship are formed, challenged, adapted and reinvented through public discourse by both citizens and non-citizens. This is where citizenship is enacted by a wide range of agents through performative rhetoric and being. Robert Asen in his article, $A$ Discourse 
Theory of Citizenship, extends a view of citizenship as praxis and not a possession or a natural endowment. When theorizing citizenship, Asen proposes we shift our perspective from "what constitutes citizenship to how citizenship proceeds" (Asen, 194). This conception highlights the performativity of citizenship in which the political dimension is constituted of.

\subsection{Social Dimensions of Citizenship}

Socially, citizenship is both a symbol and sense of belonging to an imagined community that collectively maintains political, material, and spiritual rights and access to its members. Thus, citizenship becomes a form of identity, which intrinsically becomes tied to the soil in which the state lays claim to, and the historical and modern translations of law and agency by members who hold power. Understanding of who belongs occurs in both formal and informal settings that solidifies our shared practices and conceptions. It also is to be said that "informal understandings are always linked into the more institutional specifications" about citizenship (Painter \& Philo, 1995, p.115). These three dimensions are relevant to both the historical and modern conception of citizenship.

\subsection{Contingency}

Benedict Anderson's and Robert Asen's work bring up two important aspects of citizenship, that the legal, political, and social dimensions most commonly spoke of do not. What I am referring to is time and translation, their relation to one another, and our understanding of the concept of citizenship (Balibar, 2010, 320). Citizenship, in its vernacular mode of understanding, is both temporally and spatially dependent. Translation, in the sense of both movement and garnering meaning, is the tool in which time and space give power to recognizing 
someone's status as a co-citizen. Spatially, both the territory within and outside the conceptualized community adds blood to soil by our translation of which lineages and what bodies of people are deemed worthy to live fully in a given space.

Temporarily, those who may not be considered a citizen or a migrant, over time may become one, through their and the community's translation of such. This understanding is grounded in the belief that citizenship is not solid, but fluid, and through time and translation it becomes dynamic and socially determined. Knowledge and power, laws and discourse, tend to claim an antiquity of such a mode of belonging that hides this truth. And furthermore hides a connection/process that may be conceptualized but has yet to be recognized in any formal sense.

Dr. Eva Youkhana, who studies space and material semiotic perspectives on migration, collective action and belonging, posits a space-sensitive approach that will be applied to the analysis of the material conditions and performative rhetorics mediated through my collected data. Drawing from spatial and material perspectives of scholars like Lefebvre and Latour, Youkhana pays attention to space as a product of natural, political, social, economic and cultural interactions. Tying in the intersectional approach from the work of Yuval-Davis and Floya Anthias that focuses on different social formations and contestations; a space-sensitive approach includes an analysis of socio-material conditions to observe everyday practices of belonging and enactments of citizenship. Youkhana develops her own space-sensitive definition of belonging as

"a socio-material resource that arises by means of multiple and situated appropriation processes. Belonging describes alterable attachments that can be social, imagined, and sensual-material in nature. The material-semiotic and space-sensitive study of 
belonging reveals activities that produce belonging on different temporal and spatial platforms and within more or less institutionalized (repeated, performed, etc.) everyday practices, (imposed) rituals, and "regimes of belonging" (2015, p. 16).

This definition of belonging brings attention to coroperal experiences, allocations of resources, institutional practices, and material cultural productions that serve as carriers for social boundary marking (Youkana, 2015, p. 16). From this perspective we can analyze the shifting of belonging that continually occurs through repetitive rhetoric and material performances. Such occurrences can be revealed by paying attention to everyday communication and the social production of space and material conditions. Likewise the strategic processes of exclusion that such performances contest, are unveiled in their political, socio-economic, institutional, and knowledge systems (Youkana, 2015, p. 20). This approach to belonging and understanding of citizenship will guide my analysis and discussion of the data collected concerning those in the state of Oregon. Missing from this research is Youhkana's attention to "creative poetic acts" that serve as symbolic representations of belonging being formed from experiences and choices, rather than "imposed identities, genealogies, and positionalities" (2015, p. 15). In which a space-attentive approach to belonging also focuses on creative objects that embody resistances to social classifications, like citizenship, and allocations.

As it functions now, and potentially in whatever expanded conception, recognition of citizenship is highly particularistic, based upon legal dimensions that subvert the processes of becoming of belonging. This becomes problematic when citizenship is coupled with rights and 
access to necessary materials for human life. If there is doubt to this last statement, we need only to open our ears, hearts and minds to the abundance of testimonies of those who tend to the lands of which our food grows, serve meals, build buildings, and before I get too particularistic, contribute to communities in a variety of ways.

\section{Methodology}

There is a conversation to be had of who should be speaking for and within any given community. My focus and data provided will be centered around those who do not hold full-citizenship status, as it pertains to the theoretical dimension laid out above. This consists but is not limited to migrant, immigrant and refugee identities, as it relates to the issues of citizenship and belonging during COVID-19.

\section{Thesis Questions:}

How has Covid-19, shifted local notions of belonging for groups without full citizenship? How does the lack of citizenship affect material and imaginative boundaries within the state?

\section{Data Collection}

Media. Due to safety precautions for the COVID-19 pandemic, the data I used to create themes to analyze was strictly pulled from three local media digital sources. These three sources were The Oregonian, The Willamette Week, and The Portland Tribune. I searched for articles that focused and mentioned non \& sub-citizens such as (un)documented immigrants, migrants, and refugees. Non \& sub-citizens were determined by missing placement in one or all three dimensions of citizenship. Data was extracted from a specific timeline, ranging from the beginning of March- shortly after Forest Hills Elementary School custodian, Hector Calderon, 
became the first COVID-19 patient - to the end of June. In total I gathered 40 news articles

describing a range of events, rhetorics, behaviors, material conditions, emotions, and actions that would be translated into recurring themes for analysis.

\section{Data Analysis}

I used a qualitative research method, axial coding, to connect data I pulled from media sources to reveal codes, subcategories and themes about non-citizens. My process consisted of locating links between data; which was organized into open codes like behaviors, events, activities, strategies, states, meanings, participation, relationships, conditions, and consequences. The SAGE Encyclopedia of Communication Research Methods described these open codes as the following:

Behaviors refer to specific behavioral acts that occur. Scholars often agree that events are single occurring instances. Such instances may be once in a lifetime or instances shared in narrative format. Activities, on the contrary, refer to instances that occur throughout a longer duration and might also be continuous in nature. Strategies refer to specific identifiable practices in communicative events or activities. States refer to general physical, mental, and emotional conditions that individuals experience. Meanings are a diverse phenomenon that influences how participants act, how they might act, and how they believe they will act or others should have acted. Relationships are essential linked interactions in which participants derive, construct, and reconstruct some type of meaning that is perceived to be beneficial. Conditions may also be referred to as constraints and may be anything that influences the context of interaction.

Consequences refer to rewards and costs of specific behavior, events, activities, or 
actions. Finally, settings refer to the communication of the event or activity. (Simmons, 2018, p. 2).

Before open coding, I created memos, a writing process "in which a researcher reflects upon her or his findings in written communication with oneself. This consisted of gathering quotes and initial thoughts of the collected data. Afterwards, I coded the items gathered - recurring events, strategies, relationships, etc. - from all three months of data. This was then translated into sub-categories that became evident from reading and re-reading the coded data. After establishing sub-categories, the data was reread again to ensure accurate reflection of the communicative events mediated through the media. The sub-categories revealed insight to paradigm elements such as casual conditions, context, strategies, and consequences. Casual conditions refers to events and activities that lead up to a theme. Context are specific sets of conditions that influence strategies. Strategies or intervening conditions is a reference to verbal and non-verbal interactions that reveal how a theme is managed, enabled, and contested. Consequences are the intended and unintended results of strategies that interact with emergent themes. These elements were used to form linkages between the data and underlying themes for analysis (Simmons, 2018, p. 3-4).

\section{Analysis}

In this section I will describe the themes that emerged from my analysis of the communicative performances, actions, relationships, and the socio-spatial and material conditions provided by the data. These themes reveal the influence of space-sensitive interactions to the political project of belonging; highlights the inequitable outcomes of current practices of "regimes of belonging" and processes that continue, contest, and shift social 
belonging and "othering". These themes are: non and sub-citizens are both 1.) Highly exposed 2.) and invisible 3.) Low paid, unprotected, work, largely held by immigrants is essential to the state 4.) Activists 'appropriate' spaces of citizenship to secure political gains as well as challenge our notion of citizenship/belonging itself.

These themes garnered from axial coding creates an overarching theme of socio-spatial production processes exposed by COVID-19 reveal wider forms belonging outside the conception of citizenship, and instruments of 'distancing' that had such forms of belonging.

\subsection{Highly Exposed}

Shortly after Hector Calderon, the first COVID-19 patient in Oregon, was infected from community spread, both The Willamette Week and The Oregonian reported on the effects the virus was beginning to have on the Portland community. These first stories covered the reports of rising xenophobic and racist behaviors toward immigrant communities and the subsequent downturn of buisness for Asian-American owned businesses due to myths surrounding the virus. Immigrant owned businesses, county officials and the Portland Public Schools provided statements reflecting such events (Riski, 2020; Bailey Jr., 2020a). These and the stories that followed would unravel a sub-theme of immigrants being stigmatized with the virus. Paying attention to behaviors, conditions, meanings, and strategies described by the collected articles; a variety of immigrant and refugee groups - Latinx, African, Asian, Slavic and Pacific Islanders had all dealt with stigmas concerning the virus. Racist and xenophobic behaviors toward immigrant communities were referenced specifically in combination of 19 counts. Stigmas analyzed and extracted from xenophobic behaviors and meanings gathered from the data is only 
one sub-theme that would contribute to the theme of immigrants being both invisible \& highly exposed.

Exposure, in this theme, takes on multiple meanings - exposure in certain communication strategies, exposure to the socioeconomic effects of the virus, and exposure to the virus itself in spaces disproportionately held by immigrants and refugees. Analyzing communication strategy among public officials and socio-material conditions of immigrants created linkages of codes to produce this major theme. Paying attention to the aspect of being highly exposed, actors throughout this sample produced recurring communicative strategies and activities that amplified (or ignored) immigrants' proximity to the virus and all other related ramifications.

Within the first month of data, the range of actors - public officials, experts, community leaders, and immigrants - communicated vulnerability and proximity that immigrant communities had to the virus. Before COVID-19 had even become a health pandemic, the vulnerability to the ramifications of the virus was felt by low-income immigrant workers; who were affected by layoffs or reduced hours in response to nearly a $60 \%$ decrease in revenue for Asian-owned businesses in Southeast Portland's Jade district (Bailey Jr., 2020a, para. 4). Following this, actors like Clackamas County Health Officer, Dr. Sarah Present, Susannah Morgan, Oregon Food Bank CEO, and former program officer at the Ford Foundation during hurricane Katrina all reiterated the position that immigrants were more vulnerable (Bailey Jr., 2020b, para. 8; Monohan, 2020, para.7; Depass, 2020, para. 2-3).

This strategy transgressed into correlating high and rising cases with immigrant and refugee communities. Multiple articles and a variety of actors specifically identified immigrant community groups as explanations for high cases. For example, Multnomah county officials 
communicated that barriers to reopening were the county's size and "diversity" - in comparison to other counties that have lower immigrant and refugee residents. Referring to immigrant and refugee communities, Rachael Bank's, the county's public health director reiterated in The Oregonian: "we need to have a workforce that matches what this disease actually looks like in the county" (Sickinger, 2020, para. 10).

This high exposure in communication strategy was also reflected in material-sensual conditions that immigrants experienced. Many immigrants saw "themselves as very vulnerable" not only because of the discourse in media, but because many immigrant "essential" workers were more likely to fall below the poverty line, not have medical leave, sick paid leave, or were unable to remotely work from home (Samayoa, 2020, para. 5; AP, 2020b, para. 5). These conditions were a recurring theme in the data that not only reflected their exposure in socioeconomic terms, but also could increase their spatial exposure.

As covid outbreaks in largely immigrant held workplaces became a recurring pattern, like the essential work in food processing and agricultural settings; references to "cramped" working and housing conditions was repeated a number of times throughout the data by a wide range of actors. This recurring theme links specific locations and material conditions to groups that largely inhabit them. Which becomes a reference point for the social, political, and economic forces that engender such spatial reality (Youkhana, 2015). This attention to the spatial-material conditions of immigrant workers was highlighted due to the person to person transmission of the virus. Community activists in particular preceding and after (known) workplace outbreaks focused on these particular settings to draw public and state officials attention to living and more specifically workplace settings "that force workers into close proximity and limit their ability to 
wash or sanitize" (AP, 2020c, para. 8). In these particular industries, ones "essential" to the state economy, it became apparent that many of the low paid workers were disproportionately held by immigrants, and many undocumented. Without access to any safety net, many immigrant workers felt pushed to work regardless of conditions, and those without documentation would "brush off testing because they fear it could lead to deportation" (AP, 2020d, para. 12). Thus, immigrant workers are exposed more than once; they are socially stigmatized with the virus, vulnerable to socio economic ramifications, and more likely to be physically exposed to the virus.

\subsection{Invisible}

While being highly exposed in a variety of ways, immigrants \& refugees, at the same time, were also invisible to the public and state health officials and notions of belonging. Invisible, in institutional practices and strategies, knowledge systems, and spatial awareness. The latter refers to space as "a product based on the interlocking of natural, social, political, economic, and cultural bits and pieces that simultaneously interact", and thus can be connected to social and political dimensions of citizenship (Youkhana, 2015, p. 15). David Cuevas, a contact tracer profiled by The Willamette Week, corroborated these claims, adding that jobs largely held by immigrant workers are in "a lot of industries that people don't see" (Jaquiss, 2020a, para. 62). As Cuevas highlighted the spatial aspects of this invisibility, analysis of communicative strategies, relations, and institutional conditions revealed a similar pattern. Evident in the repeated use by community members, health workers, experts, and state officials of the phrase, near verbatim, "I think this pandemic/crisis has shown us $\mathrm{x}, \mathrm{y}$, and z". This phrase often pointed out economic inequality, essential relationships with immigrant and refugee 
communities, gaps in services, material conditions, and disconnection from the rest of the community. For example - after detailing the socioeconomic conditions of "essential" workers, who are more likely to be POC and immigrants, David Michaels, a professor of environmental and occupational health, contributed a statement to an article cycled by The Oregonian: "What is important about this pandemic is that it shined a spotlight on workers who have always been essential but before this were invisible" (AP, 2020b, para. 6). Statements like these implicate that before the pandemic, such groups were hidden from spaces of belonging. This attention to the performances of belonging, like recurring activities of essential work, "allow us to better understand which instruments are used in the processes of 'othering' or distancing, and by whom these processes are sustained" (Youkhana, 2020, p. 20).

Analysis of communicative strategies, conditions and activities revealed how state and public health institutions contributed to the invisibility of immigrants and refugees. A lack of transparency was a recurring issue that left immigrant workers feeling more endangered and not "together" in this pandemic with the rest of the community (McDaniel, 2020, para. 33). Such meanings and states reflected in the data are important to note because "productions of belonging are related to senses of unbelonging", triggered by 'othering' processes (Youkhana, 2015, p. 20). Gov. Kate Brown's initial orders to prevent the spread of the virus was unclear how such restrictions would apply to agricultural and food processing work settings (McDaniel, 2020, para. 17). Multiple county officials "were slow to get timely information about COVID-19 to agricultural workers and non-English speaking residents" (Salem Reporter, 2020, para. 7). Likewise, the pandemic showed "decade-old structural issues - including racism and disparities in health care" (Shimidt, 2020, para. 26). Health officials acknowledged that relationships with 
immigrant and refugee communities to effectively translate information had to be started from the ground up (Tebor, 2020b, para. 3). Language barriers, across all three months of data, was a recurring issue for immigrants receiving critical information about the pandemic, and relief for those who had access to a safety net. For Dr. Jennifer Vines, Multnomah County's health officer, the pandemic was “a 'renewed lesson' about the importance of ongoing relationships with refugee and immigrant community leaders" (Tebor, 2020b, para. 6).

The state's largest concentration of cases (at the time) at Townsend food processing plant, a setting largely occupied by immigrant workers, was initially undisclosed to the public. After The Willamette Week revealed the Townsend event, the Oregon Health Association (OHA) announced a reversal in policy that previously left workplace outbreaks out of public reports. Adriana Ryder, advocate for immigrant farm workers said this reversal "was a tactic admission that Oregon's policy hurt the most victimized by COVID-19” (Jaquiss, 2020d, 3.1, para. 5). Immigrant rights activists like Ryder pushed Oregon to address spatial and socioeconomic conditions of immigrant workers. Emergency measures that followed continued to produce the same theme of nontransparent actions and strategies by state officials.. "Who is monitoring that these emergency measures are taking place?" asked Oregon Employment Department employee Fernando Gutierrez. While referring to the new OHA measures for employers to make changes to labor housing, transportation, and field sanitation, Gutierrez added, “The problem is nobody is actually doing that" (Goldberg, 2020b, para. 25). Consistently, systemic disconnections in institutions and actions by state and health officials continued to hide immigrant and refugee enactments of belonging and their material conditions.

\subsection{Essential}


"Essential workers" was a dominating term that became linked to people of color and immigrants and refugees. It unveiled the essential services that were disproportionately performed by said groups, correlated socioeconomic conditions, and a spatial awareness that previously was unnoticed by the majority of the public. Analysis of coded activities, strategies, states, conditions and relationships revealed that low-paid, unprotected work, largely held by immigrants was essential to the state. The sample of articles largely focused on agricultural and food processing work settings, where many immigrant workers help produce premier wine, plant and pick berries, hazelnuts, christmas trees, and process the region's food. The majority of essential workers in these settings were latinx immigrants, many undocumented. Analyzing coded states, conditions, and relationships, these essential workers were less likely to have access to adequate health care or unemployment services. Contact tracers repeatedly expressed situations where they come across essential workers, a lot undocumented who "brush off testing because they fear it could lead to deportation; and "where families all felt sick and they dont have money for food or rent so they feel like they have to go to work" (Jaquiss, 2020a, para. 69; AP, 2020, 2.10, para. 16).

Latinxs make up 13.3 percent of the state's population, but at times were representing nearly a third of all coronavirus cases. In response, activists voiced concerns about the "cramped" work and living spaces, common in essential farm and food processing work. This attentiveness to space became a recurring theme in discussing high cases in immigrant groups, specifically in agricultural and food processing work places. Such conditions "prevent the social distancing and hygiene necessary to stall COVID-19” (McDaniel, 2020, para. 4). This resulted in new OHA measures that Guitierezz previously mentioned. Before being implemented, the proposal of 
policies requiring more space to sleep for workers "horrified farmers in Oregon and

Washington" (Mesh, 2020, para. 8). The Oregon Farm Bureau, which represents nearly 7,000 farms and ranches, expressed opposition to OHA policy changes (McDaniel, 2020,para. 29). One reporter summarized this section's theme in one sentence: "The price and availability of apples in grocery stores this fall could come down to a critical question on the farm: whether migrant workers should sleep in bunk beds" (Mesh, 2020, para. 9). Thus, before and after the emergence of the coronavirus; immigrant held, unprotected, "cramped" working and living conditions for farms and food processing centers was essential.

\subsection{Expansion of Citizenship}

The last recurring theme in this section of my analysis is the expansion of citizenship and the appropriation of such spaces led by community leaders and activists. This theme emerged from coded strategies, states, relationships, and consequences that revealed that many expansions of institutional protections for immigrants, afforded to by the state, were led by community activists; who drew attention to the performativity of belonging and their spatial reality. Likewise, they appropriated spaces of citizenship - providing essential information, relief, and representation at a political level, in place of institutional access and representation that many immigrants do not share.

Expansions of worker protection for immigrants, state grants as small form of unemployment relief for undocumented workers, and reversal of policies that harmed immigrants those most, were all spearheaded by community leaders and immigrant activists. The data revealed specific rhetorical strategies used by leaders and activists; drawing on repetitive practices, like the "essential" services (and their taxes) that immigrants provide, to link collective 
behavior and constructions of attachments. Organizations like PCUN pushed government leaders to extend unemployment insurance (Samayoa, 2020, p.12); the nonprofit Oregon Law Center filed petitions for OHA to address "cramped" workplace conditions and provide workers with access to healthcare (McDaniel, 2020, para. 6); lawyers from nonprofits like the Metropolitan Public Defender and Immigrant \& Refugee Community Organization, urged Portland city commissioners to "continue paying to provide free court-appointed attorneys to defend Portland residents in immigration court” (Bailey Jr., 2020c, para. 14) ; and immigrant worker advocate, Adriana Ryder, helped reveal one of Oregon's largest workplace outbreak, many undocumented immigrants, that was previously undisclosed to the public. All these pushes for expansion of belonging relied on amplifying social relations and everyday activities embodied in the term “essential workers", references to immigrants as residents and neighbors, and recognition of humanness.

Simultaneously, while immigrant workers burdened with essential work; community leaders and activists provided essential services like economic relief, legal and political representation, and access to critical information. These activities appropriated spaces of citizenship that are in larger extent afforded to "legal" citizens in the community by the nation-state system. Analyzing strategies and relationships revealed that immigrant and refugee communities primarily used social media, from community organizations, for their source of important health information. The Oregon Worker Relief Fund was brought forward by multiple organizations that serve immigrant communities like Causa Oregon, Innovation Law Lab, and the Asian Pacific American Network of Oregon. Coded states and meanings revealed a strong sense of belonging to community members that supported each other; like Som Subedi, a refugee 
who resettled in Portland, who felt "grateful for his community and the support within it" (Tebor, 2020c, para. 39). Such actions and representations for immigrant communities provided both an expansion of citizenship and enactments of.

\section{Discussion}

The events, conditions, activities, and responses during this sample showed how COVID-19 exacerbated social and political issues of belonging for residents in Oregon who do not hold full citizenship status. Analyzing the material and communicative activities of immigrants, refugees and officials, reflected a disconnection between knowledge systems, institutions, and procedures of recognition for residents who contribute to the public sphere. Many immigrant and refugee communities who consistently produce essential services for the state were "invisible" to state and health officials during a deadly pandemic. Simultaneously they were also highly exposed to specific public behaviors (racism and xenophobia), stigmas, proximity to the virus, and negative health and socioeconomic effects exacerbated by their institutional invisibility.

The data revealed that responses to COVID-19 created an attachment of "essentialness" to immigrant and refugee communities. Officials and media discourse both in local and national settings confirmed that "essential workers" were more likely to be people of color, immigrants, and refugees. Due to this institutional recognition of essential relations between said groups; this term was appropriated by immigrants, community leaders, and activists to expand the spaces of citizenship and attachments of belonging in both institutional and public settings through 
rhetorical performances. These performances took shape in petitions to the state, descriptions of the civil duties immigrants and refugees perform, and the conditions they face in contrast to legal citizens. Such communication strategies and conditions brought on by the coronavirus resulted in the public, health and state officials recognition that the pandemic "revealed" important relationships and the lack of connection in a variety of settings.

While attention to the community services provided by immigrants and refugees increased; it also produced an awareness of social and material conditions non and sub-citizens deal with. Community organizer Michelle LaRue stated, "I think this pandemic has really highlighted issues that always plagued our community and we've been fighting to overcome" (AP, 2020f, para. 28). Because of the characteristic of the virus transmission, leaders and activists focused public and state attention to "cramped" work and living conditions. Sensitivity to space allowed for analysis and challenges to socio-spatial productions processes. Within this theme a connection was made between physical spaces and inhabitants; such as immigrant workers in food processing centers, to social and political spaces that contribute to such spatial reality. Recurring discussion around poverty, access to health care, unemployment services, and access to information exposed the inequitable and damaging effects of coupling rights and access to social safety nets tied with citizenship.

Lastly, the data revealed expansions of citizenship through increased engagement with performances of belonging. Amplified by COVID-19 with the advent of "essential" work and a hyperfocus of spatial construction due to the community spread of the virus; increased attention to spaces largely populated by immigrants and refugees highlighted a challenge to legal, political, and social dimensions of citizenship. Drawing from Youkhana's space-attentive 
approach to belonging, "the social is lived, perceived, and conceived in space, while also creating space socially" $(2015$, p. 15$)$. This allowed for engagement with and challenges to belonging by drawing attention to everyday activities performed by immigrants and refugees and their implications of social and political attachments. In an effort to expand notions of citizenship to address material and socioeconomic conditions, community leaders and activists appropriated legal, political, and social dimensions of citizenship; which provided real (but inadequate) expanded state protection to non-citizens.

\section{Conclusion}

In the midst of Covid-19, residents who lack full citizenship status in Oregon have disproportionately been affected by the negative economic and health outcomes of the pandemic. Brought forward by the characteristic of the virus, "essential" relationships between citizens and non-citizens challenged previous notions of belonging and dimensions of citizenship. The data revealed the role spatial awareness had in linking and challenging processes of "othering" in specific institutional settings.

Currently and too often, rights and access to resources are coupled with all three dimensions of citizenship, the political, social and legal. By focusing on essential performances immigrants and refugees inact, and their embodied spatial experiences, the boundary maintenance of citizenship is revealed. Evident in communicative strategies state officials conducted to hide outbreaks in immigrant spaces, lack of transparency for specific communities, and institutional structures that previously devalued relationships with immigrant communities. Citizenship as a necessary condition for access to rights and other material essentials blurs the processes of belonging that occurs through relations founded on everyday activities, corporeal 
experiences, emotional and social attachments. Gloria Anzaldua described the US-Mexican border as " una herida abierta", an open wound, "where the Third World grates against the first and bleeds" (1987, p. 25). The relational and spatial awareness propagated by the coronavirus brings attention to the social realities created by regimes of belonging that scrape against those without access to all dimensions of citizenship, but are still essential to the community.

Pulling from theories of belonging and citizenship as something performed (Asen, 2014; Cisneros, 2013; Youkhana, 2015), rather than possessed, pushes us to examine the everyday activities and social attachments formed and being formed. In a world where the nation-state is the dominant political regime of belonging, it is imperative to give attention to the socio-material productions of citizenship. Strictly because it affects peoples lives. The data not only revealed performances and expansions of belonging; it also revealed the hardships people face against fixed boundaries, material and social. Citizenship as a bearer of rights, access, and recognition transforms belonging as something that is fluid and socially constructed into a rigid and natural possession. Not interrogating these processes allows the inequitable outcomes that are physically embodied to be legitimized. The data revealed that these material conditions and "essential" connections to immigrants and refugees were 'invisible' to many. Since no one was actually invisible in terms of somes translucent body, we ought to take this notion as a shifting of norms. Which previously, the material conditions and forms of belonging were hidden in plain sight.

As I stated in my introduction, I wanted to initially conduct a project to analyze borders in Portland and the surrounding area. I had this feeling that there would be clear markers of divided material and imaginative spaces - where people felt different senses of belonging derivative of social meaning, objects, economic, political, and sensual-material conditions. 
Because of the coronavirus I and many others have had to confront, and reevaluate, our spaces and the relationships they are made of. This transformed my project into considering the overarching processes that inform our conception of space and who belongs to it. Concerning myself with borders, I moved to researching the social bordering process of citizenship, which materializes into the allocation and division of resources and space.

COVID-19 and its attention to space brought focus to specific social and physical locations, like the Portland Jade District, farms, and food processing centers. This revealed the many who occupy such space, socio-material conditions, and their connections to wider community building processes. Focusing on everyday activities, material conditions, and performances of belonging that immigrants and community leaders enacted; processes that challenge and maintain notions of citizenship, the dominant political regime of belonging, come to light. Like borders, the social divisioning of citizenship is both inclusionary and exclusionary. COVID-19 produced an awareness of our connections across statuses of citizenship, and revealed its production of boundaries as something "linked effectively with the social and spatial division of labour, the control of resources and social differentiation" (Paasi, 1998, p. 81). Moving forward from here, we could apply this becoming of belonging to other physical and social locations, and creative poetic acts in Portland and the surrounding area; in effort to link how citizenship and other regimes of bordering affect, manage, and contest our connections and lived experiences in settings outside of the workplace. 


\section{References}

Anderson, B. (2006). Imagined communities : Reflections on the origin and spread of nationalism (Rev. ed.). London; New York: Verso.

Anthias, F. (2015). Interconnecting boundaries of identity and belonging and hierarchy-making within transnational mobility studies: Framing inequalities. Current Sociology, 64(2), 172-190.

Anzaldúa, G. (1987). Borderlands : The new mestiza = La frontera (1st ed.). San Francisco: Spinsters/Aunt Lute.

Asen, R. (2004). A discourse theory of citizenship. The Quarterly Journal of Speech, 90(2), 189-211.

Associated Press. (2020a, April 15). California to give cash to immigrants in the country illegally who are left out of coronavirus stimulus package. The Oregonian. Retrieved from https://www.oregonlive.com/coronavirus/2020/04/california-to-give-cash-to-immigrants-i n-the-country-illegally-who-are-left-out-of-coronavirus-stimulus-package.html

Associated Press. (2020b, May 1). Women, minorities shoulder front-line work during coronavirus pandemic. The Oregonian. Retrieved 2020, from https://www.oregonlive.com/coronavirus/2020/05/women-minorities-shoulder-front-linework-during-coronavirus-pandemic.html

Associated Press. (2020c, May 9). Coronavirus cases at Astoria seafood plant rise to 26. The Oregonian. Retrieved 2020, from 
https://www.oregonlive.com/coronavirus/2020/05/coronavirus-cases-at-astoria-seafood-p $\underline{\text { lan-rise-to-26.html }}$

Associated Press. (2020d, May 21). Coronavirus contact tracers play many roles: Detective, nurse, confidant. The Oregonian. Retrieved 2020, from https://www.oregonlive.com/coronavirus/2020/05/coronavirus-contact-tracers-play-many $\underline{\text {-roles-detective-nurse-confidant.html }}$

Associated Press. (2020e, June 19). Trump says he will renew effort to end DACA protections for Dreamers. The Oregonian. Retrieved 2020, from https://www.oregonlive.com/nation/2020/06/trump-says-he-will-renew-effort-to-end-dac a-protections-for-dreamers.html

Associated Press. (2020f, June 20). Coronavirus ravages Latino communities in the U.S. The Oregonian. Retrieved 2020, from https://www.oregonlive.com/coronavirus/2020/06/coronavirus-ravages-latino-communiti es-in-us.html

Bailey Jr., E. (2020a, March 19). Nearly \$200,00 in grants could reach Portland small businesses hurt by coronavirus. The Oregonian. Retrieved August, 2020, from https://www.wweek.com/news/2020/03/04/racist-fears-are-driving-down-business-at-port lands-asian-restaurants-multnomah-county-says/

Bailey Jr., E. (2020b, March 19). Shelter in place policy not necessary to avoid coronavirus, Portland health officials say. The Oregonian. Retrieved August, 2020, from 
https://www.oregonlive.com/coronavirus/2020/03/nearly-200000-in-grants-could-reach-p ortland-small-businesses-hurt-by-coronavirus-next-week.html

Bailey Jr., E. (2020c, May 13). Portlanders suggest more money in proposed city budget for renters and immigrant aid, less for police. The Oregonian. Retrieved 2020, from https://www.oregonlive.com/portland/2020/05/portlanders-suggest-more-money-in-propo $\underline{\text { sed-city-budget-for-renter-and-immigrant-aid-less-for-police.html }}$

Balibar, E. (2010). At the Borders of Citizenship: A Democracy in Translation? European Journal of Social Theory, 13(3), 315-322.

Benhabib, S. (2009). Claiming Rights across Borders: International Human Rights and Democratic Sovereignty. American Political Science Review, 103(4), 691-704. Benhabib, S. (2004). The rights of others aliens, residents and citizens /. Cambridge ;: Cambridge University Press.

Berlant, L. (2014). Citizenship. In Burgett B. \& Hendler G. (Eds.), Keywords for American Cultural Studies, Second Edition (pp. 41-45). NYU Press.

Blokland, T., Hentschel, C., Holm, A., Lebuhn, H. and Margalit, T. (2015), Urban Citizenship and Right to the City: The Fragmentation of Claims. Int J Urban Regional, 39: 655-665.

Bloemraad, I. (2008). Citizenship and Immigration: Multiculturalism, Assimilation, and Challenges to the Nation-State. Annual Review of Sociology., 34(1), 153-179. 
Brunet-Jailly, Emmanuel. "Special Section: Borders, Borderlands, and Theory: An Introduction ." Geopolitics, vol. 16, no. 1, 18 Feb. 2011, pp. 1-6. Taylor \& Francis Online, doi:https://doi.org/10.1080/14650045.2010.493765.

Calame, Jon., and Charlesworth, Esther Ruth. Divided Cities : Belfast, Beirut, Jerusalem, Mostar, and Nicosia. University of Pennsylvania Press, 2009.

Cisneros, J., \& Watson, Mary Elizabeth. (2013). The border crossed us : Rhetorics of borders, citizenship, and Latina/o identity (Rhetoric, culture, and social critique). Tuscaloosa, Alabama: University Alabama Press.

Collins, K. A. (2014). Illegitimate Borders: "Jus Sanguinis" Citizenship and the Legal Construction of Family, Race, and Nation. The Yale Law Journal, 123(7), 2134-2235.

DePass, M. J. (2020, April 1). Opinion: Get through today but remake tomorrow. The Oregonian. Retrieved from https://www.oregonlive.com/opinion/2020/04/opinion-get-through-today-but-remake-tom orrow.html

Eade, J. (Ed.), Rumford, C. (Ed.). (2018). Re-Living the Global City. London: Routledge, https://doi-org.proxy.lib.pdx.edu/10.4324/9781315717586

Ferguson, B. (2020, May 5). Latinx Theater Company Milagro Fights the Pandemic Blues With YouTube Shorts. The Willamette Week. Retrieved 2020, from 
https://www.wweek.com/arts/2020/05/05/latinx-theater-company-milagro-fights-the-pan demic-blues-with-youtube-shorts/

Heater, D. (2004). A Brief History of Citizenship. Edinburgh: Edinburgh University Press. doi:10.3366/j.ctvxcrsq8

Glenn, E. (2011). Constructing citizenship: Exclusion, subordination, and resistance. American Sociological Review., 76(1), 1-24.

Goldberg, J. (2020a, June 14). Coronavirus outbreaks surge among Oregon food processors as state scrambles to react. The Oregonian. Retrieved 2020, from https://www.oregonlive.com/coronavirus/2020/06/coronavirus-outbreaks-surge-among-or egon-food-processors-as-state-scrambles-to-react.html

Goldberg, J. (2020b, June 28). Farmworker advocates worry Oregon's protections won’t keep laborers safe from coronavirus as harvest season ramps up. The Oregonian. Retrieved 2020 , from https://www.oregonlive.com/coronavirus/2020/06/farmworker-advocates-worry-oregonsprotections-wont-keep-laborers-safe-from-coronavirus-as-harvest-season-ramps-up.html

Gunderson, L., \& Herbert, B. (2020, May 2). May Day protests call for more coronavirus protections for workers. The Oregonian. Retrieved 2020, from https://www.oregonlive.com/coronavirus/2020/05/may-day-protests-call-for-more-corona virus-protections-for-workers.html 
Hammond, B. (2020, June 6). Oregon lawmakers agree to devote $\$ 247$ million in federal coronavirus aid to renter relief, rural hospitals, child care and more. The Oregonian. Retrieved 2020, from https://www.oregonlive.com/coronavirus/2020/06/oregon-lawmakers-agree-to-devote-24 7-million-in-federal-coronavirus-aid-to-renter-relief-rural-hospitals-child-care-and-more. $\underline{\text { html }}$

Jaquiss, N. (2020a, May 20). Reopening Oregon Depends on a Detective Squad Tracing Where Contagious People Have Been. The Willamette. Retrieved 2020, from https://www.wweek.com/news/2020/05/20/reopening-oregon-depends-on-a-detective-squ ad-tracing-where-contagious-people-have-been/

Jaquiss, N. (2020b, May 28). Oregon Officials Say COVID-19 Outbreak at Townsend Farms Affects 48 of 350 Newly Arrived Seasonal Workers. The Willamette Week. Retrieved 2020, from https://www.wweek.com/news/2020/05/28/oregon-officials-say-townsend-farms-covid-1 9-outbreak-affects-48-of-350-newly-arrived-seasonal-workers/

Jaquiss, N. (2020, May 29). Oregon Worker Relief Fund Begins Distributing Cash to Immigrants Harmed by COVID-19. The Willamette Week. Retrieved 2020, from https://www.wweek.com/news/2020/05/29/the-oregon-worker-relief-fund-begins-distribu $\underline{\text { ting-cash-to-immigrants-harmed-by-covid-19/ }}$ 
Jaquiss, N. (2020, June 3). It Took an Advocate for Farmworkers to Do What Gov. Kate Brown Wouldn't—Reveal Oregon's Largest Workplace Outbreak. The Willamette Week. Retrieved 2020, from https://www.wweek.com/news/2020/06/03/it-took-an-advocate-for-farmworkers-to-do-w hat-gov-kate-brown-wouldnt-reveal-oregons-largest-workplace-outbreak/

Johnson, Corey, Jones, Reece, Paasi, Anssi, Amoore, Louise, Mountz, Alison, Salter, Mark, \& Rumford, Chris. (2011). Interventions on rethinking 'the border' in border studies. Political Geography, 30(2), 61-69.

Komarova, M. (2014). Mundane Mobilities in 'Post-Socialist' Sofia: Making Urban Borders Visible. Etnofoor, 26(1), 147-172.

Kofman, E. (n.d.). Citizenship, Migration and the Reassertion of National Identity. Citizenship Studies., 9(5), 453-467.

Lefebvre, Henri, . (1991). The production of space /. Oxford, UK :: Blackwell Publishing. Lundberg, A. (2015). Review : Sanctuary Practices in International Perspectives: Migration, Citizenship, and Social Movements ed. by Randy K. Lippert \& Sean Rehaag. Human Rights Quarterly, 37(3), 810-814.

Manville, P. (2014). The Origins of Citizenship in Ancient Athens (Course Book ed., Princeton Legacy Library ; 1058). Princeton, NJ: Princeton University Press.

Mbembe, A., \& Corcoran, Steve. (2019). Necropolitics (Theory in forms). Durham: Duke University Press. 
McDaniel, P. (2020, April 18). Oregon weighs stricter regulations to protect migrant farmworkers at risk of catching coronavirus. The Oregonian. Retrieved 2020, from https://www.oregonlive.com/coronavirus/2020/04/oregon-weighs-stricter-regulations-toprotect-migrant-farmworkers-at-risk-of-catching-coronavirus.html

Meena, K. (2013). Border theory and Globalization. International Studies (New Delhi), 50(1-2), $1-15$.

Mesh, A. (2020, May 10). A Ban on Bunk Beds Showcases Tensions Over Worker Safety as Oregon's Fruit-Picking Season Begins. The Willamette Week. Retrieved 2020, from https://www.wweek.com/news/2020/05/10/a-ban-on-bunk-beds-showcases-tension-overworker-safety-as-oregons-fruit-picking-season-begins/

Monahan, R. (2020, June 22). As Cases Rise in Multnomah County, Officials Offer an Explanation: Clusters in Families. The Willamette Week. Retrieved 2020, from https://www.wweek.com/news/city/2020/06/22/as-cases-rise-in-multnomah-county-offici als-offer-an-explanation-clusters-in-families/

Muller, Peter O. "Twenty-First Century Gateways: Immigrant Incorporation in Suburban America - Edited by Audrey Singer, Susan W. Hardwick, and Caroline B. Brettell.” Growth and Change, vol. 40, no. 2, 2009, pp. 376-380.

Nail, T. (2016). Theory of the border. Oxford ; New York: Oxford University Press.

Narrowmore, B. (2020, April 23). My View: Let's build the Oregon we need. The Portland Tribune. Retrieved 2020, from 
https://pamplinmedia.com/pt/10-opinion/463923-376229-lets-build-the-oregon-we-need? $\underline{\text { wallit_nosession }=1}$

Newman, David. "Borders and Bordering: Towards an Interdisciplinary Dialogue.” European Journal of Social Theory, vol. 9, no. 2, May 2006, pp. 171-186, doi: $10.1177 / 1368431006063331$.

Paasi, A. (1998). Boundaries as social processes: Territoriality in the world of flows. Geopolitics, $3(1), 69-88$.

Painter, J. (1995). Spaces of citizenship: An introduction. Political Geography., 14(2), 107-120.

Pamplin Media Group. (2020, June 18). Oregon: Face masks required indoors in tri-county area. The Portland Tribune. Retrieved 2020, from https://pamplinmedia.com/pt/9-news/470682-380869-oregonians-react-to-supreme-courtruling-on-daca-pwoff?wallit nosession $=1$

Perry, D. (2020, April 23). Oregon immigration experts say Donald Trump's executive order is little more than racial scapegoating. The Oregonian. Retrieved 2020, from https://www.oregonlive.com/politics/2020/04/oregon-immigration-experts-say-donald-tru mps-executive-order-is-little-more-than-racial-scapegoating.html

Riski, T. (2020, March 4). Racist Fears Are Driving Down Business at Portland's Asian Restaurants, Multnomah County Says. Retrieved August, 2020, from https://www.wweek.com/news/2020/03/04/racist-fears-are-driving-down-business-at-port lands-asian-restaurants-multnomah-county-says/ 
Rosbrook Thompson, J. (2014). 'I'm local and foreign': Belonging, the city and the case for denizenship. Urban Studies., 52(9), 4294967295-1630.

Roy, A. (2019). The city in the age of Trumpism: From sanctuary to abolition. Environment and Planning D: Society and Space, 37(5), 761-778. https://doi.org/10.1177/0263775819830969

Rumford, C. (2011). Interventions on Rethinking 'the Border' in Border Studies. Political Geography., 30(2), 61-69.

Salem Reporter. (2020, May 14). Supply shortages, delayed response preceded Marion County coronavirus outbreak: Report. The Oregonian. Retrieved 2020, from https://www.oregonlive.com/coronavirus/2020/05/supply-shortages-delayed-response-pre $\underline{\text { ceded-marion-county-coronavirus-outbreak-report.html }}$

Samoya, M. (2020, March 23). Immigrant communities in Oregon struggle to access coronavirus information. The Oregonian.

Schmidt, B. (2020, June 22). Coronavirus spike in Multnomah County Linked to Spread Among Friends, Family, Officials Say. The Oregonian. Retrieved 2020, from https://www.oregonlive.com/coronavirus/2020/06/coronavirus-spike-in-multnomah-count y-linked-to-spread-among-friends-family-officials-say.ht

Senn, L. (2020, June 12). Opinion: Amid pandemic, city and Multnomah County must step up housing facilities for the houseless. The Oregonian. Retrieved 2020, from 
https://www.oregonlive.com/opinion/2020/06/opinion-amid-pandemic-city-and-multnom ah-county-must-step-up-housing-facilities-for-the-houseless.html

Sharma, Nandita. (2015). Strategic Anti-Essentialism. In McKittrick, K. Sylvia Wynter : On being human as praxis. Durham [North Carolina]: Duke University Press.

Sickinger, T. (2020, May 23). Multnomah County only one that hasn't applied to reopen, yet to meet coronavirus conditions. The Oregonian. Retrieved 2020, from https://www.oregonlive.com/coronavirus/2020/05/on-coronavirus-reopening-multnomahcounty-cautious-but-almost-there.html

Simmons, N. \& Allen, M. (2017). The sage encyclopedia of communication research methods (Vols. 1-4). Thousand Oaks, CA: SAGE Publications, Inc doi: 10.4135/9781483381411

Smith, Michael Peter, \& Guarnizo, Luis Eduardo. (2009). GLOBAL MOBILITY, SHIFTING BORDERS AND URBAN CITIZENSHIP. Tijdschrift Voor Economische En Sociale Geografie, 100(5), 610-622.

Sparling, Z. (2020, June 17). Oregon: Face masks required indoors in tri-county area. The Portland Tribune. Retrieved 2020, from https://pamplinmedia.com/rc/62-news/470663-380839-oregon-face-masks-required-indo ors-in-tri-county-area

Stokes-DuPass, N. (2016). Citizenship, belonging and nation-states in the twenty-first century. New York, NY: Palgrave Macmillan. 
Su, Rick. (2010). Immigration as urban policy. Fordham Urban Law Journal, 38(1), 363.

Torpey, J. (2000). The invention of the passport : Surveillance, citizenship, and the state (Cambridge studies in law and society). Cambridge, U.K. ; New York: Cambridge University Press.

Tebor, C. (2020, May 29). Oregon distributes masks, protective gear to farm workers amid coronavirus pandemic. The Oregonian. Retrieved 2020, from https://www.oregonlive.com/coronavirus/2020/05/oregon-distributes-masks-protective-ge ar-to-farm-workers-amid-coronavirus-pandemic.html

Tebor, C. (2020, June 30). As coronavirus cases rise among immigrant and refugee groups, Multnomah County works to rebuild relationships. The Oregonian. Retrieved 2020, from https://www.oregonlive.com/coronavirus/2020/06/as-coronavirus-cases-rise-among-immi grant-and-refugee-groups-multnomah-county-works-to-rebuild-relationships.html

Tebor, C. (2020, July 1). 'It's a retraumatizing kind of experience:' How COVID-19 is affecting refugee communities in Multnomah County. The Oregonian. Retrieved 2020, from https://www.oregonlive.com/coronavirus/2020/07/its-a-retraumatizing-kind-of-experienc e-how-covid-19-is-affecting-refugee-communities-in-multnomah-county.html

Willamette Week Staff. (2020, June 10). Ron Herndon Remembers When Portland Was Deeply Racist, Like It Was Yesterday. The Willamette Week. Retrieved 2020, from https://www.wweek.com/news/2020/06/10/ron-herndon-remembers-when-portland-wasdeeply-racist-like-it-was-yesterday/ 
Youkhana, E. (2015). A Conceptual Shift in Studies of Belonging and the Politics of Belonging.

Social Inclusion, 3(4), 10-24.

Yuval-Davis, N. (2006). Belonging and the Politics of Belonging. Patterns of Prejudice., 40(3), 197-214.

Yuval-Davis, N. (2007). Intersectionality, Citizenship and Contemporary Politics of Belonging. Critical Review of International Social and Political Philosophy, 10(4), 561-574.

\section{Appendix}

MEMO of Month 3 of Extracted Data

\begin{tabular}{|c|c|c|c|}
\hline Date & Title & Quotes \& Notes & Link \\
\hline $6 / 3$ & $\begin{array}{l}\text { It Took an } \\
\text { Advocate for } \\
\text { Farmworkers to } \\
\text { Do What Gov. } \\
\text { Kate Brown } \\
\text { Wouldn't - } \\
\text { Reveal } \\
\text { Oregon's } \\
\text { Largest } \\
\text { Workplace } \\
\text { Outbreak }\end{array}$ & $\begin{array}{l}\text { "After WW reported both outbreaks, Gov. Kate } \\
\text { Brown and OHA announced a reversal in policy. } \\
\text { Moving forward, the agency would "publicly report } \\
\text { all past and future outbreaks that involve five or } \\
\text { more COVID-19 cases in a workplace setting, no } \\
\text { matter where the outbreak is located." In so } \\
\text { doing, Brown brought Oregon's policy of } \\
\text { disclosure in line with other jurisdictions across } \\
\text { the nation. Since April 30, for instance, Los } \\
\text { Angeles County has identified all workplaces with } \\
\text { five or more cases." } \\
\text { - Media \& Policy direction } \\
\text { "This reversal, in the opinion of Adriana Ryder, } \\
47, \text { a Gresham resident who advocates for } \\
\text { migrant farmworkers, is a tacit admission that }\end{array}$ & $\begin{array}{l}\frac{\text { https://www.w }}{\text { week.com/ne }} \\
\frac{\text { ws/2020/06/0 }}{3 / \text { it-took-an-a }} \\
\frac{\text { dvocate-for-fa }}{\text { rmworkers-to- }} \\
\frac{\text { do-what-gov- }}{\text { kate-brown-w }} \\
\underline{\text { ouldnt-reveal- }} \\
\underline{\text { oregons-large }} \\
\underline{\text { st-workplace- }} \\
\underline{\text { outbreak/ }}\end{array}$ \\
\hline
\end{tabular}




\begin{tabular}{|c|c|c|c|}
\hline & & $\begin{array}{l}\text { Oregon's prior policy hurt those most victimized } \\
\text { by COVID-19." } \\
\text { - Those who are "most victimized by } \\
\text { COVID-19" established as migrant } \\
\text { farmworkers } \\
\text { "Ryder says the lack of disclosure about } \\
\text { workplace outbreaks was particularly unfair to } \\
\text { Latinx farmworkers. "They work in places that are } \\
\text { very susceptible to contamination, and they have } \\
\text { to go to work even if they are sick, because many } \\
\text { of them aren't eligible for public assistance," she } \\
\text { says. "I would like immigrant workers to have } \\
\text { rights like everybody else-to be treated like } \\
\text { humans." } \\
\text { - Official Government was intentionally } \\
\quad \text { withheld information about immigrant } \\
\quad \text { workers - what does this say about their } \\
\text { connection to the community } \\
\text { On top of being ineligible for public } \\
\text { assistance } \\
\text { Citizenship becomes a license to treat } \\
\text { others like humans } \\
\text { "In early May, Ryder, who works for the Latino } \\
\text { Network but was doing advocacy on her own } \\
\text { time, got a phone call from a young man who } \\
\text { worked at Townsend Farms' Fairview packing } \\
\text { plant. He said he was an undocumented } \\
\text { immigrant who had tested positive for COVID-19 } \\
\text { and was too sick to work." } \\
\text { "With OSHA overwhelmed and workers arriving } \\
\text { for the summer, the secrecy about CoVID-19 } \\
\text { outbreaks only added to the public health hazard. } \\
\text { Advocates say the lack of transparency } \\
\text { endangered workers and put agricultural and } \\
\text { packing plant workers in particular at risk." }\end{array}$ & \\
\hline $6 / 6$ & $\begin{array}{l}\text { Oregon } \\
\text { Lawmakers } \\
\text { Agree to devote } \\
\text { \$247 Million in } \\
\text { Federal } \\
\text { Coronavirus }\end{array}$ & $\begin{array}{l}\text { "Lawmakers spent } 2 \frac{1}{2} \text { hours questioning and } \\
\text { criticizing some aspects of the plan, but ultimately } \\
\text { cast unanimous votes in favor of all aspects of } \\
\text { the plan except paying wage replacement to } \\
\text { undocumented workers laid off amid the } \\
\text { COVID-19 scare." }\end{array}$ & $\begin{array}{l}\frac{\text { https://www.o }}{\text { regonlive.co }} \\
\frac{\text { m/coronaviru }}{\text { s/2020/06/ore }} \\
\text { gon-lawmake } \\
\text { rs-agree-to-d }\end{array}$ \\
\hline
\end{tabular}




\begin{tabular}{|c|c|c|c|}
\hline & $\begin{array}{l}\text { Aid to Renter } \\
\text { Relief, Rural } \\
\text { Hospitals, Child } \\
\text { Care, and More }\end{array}$ & $\begin{array}{l}\text { - Providing a safety net for immigrant } \\
\text { residents was the only docket that did not } \\
\text { receive unanimous votes } \\
\text { - Also when it pertains to undocumented } \\
\text { workers - covid-19 is a "scare", not a } \\
\text { health pandemic } \\
\text { "The largest single element of the package is \$55 } \\
\text { million that will be paid to landlords who rent to } \\
\text { low-income Oregonians who've lost wages } \\
\text { because of the virus." } \\
\text { - I.e., for "normal" low-income Oregonians, } \\
\text { lost wages are due to a real virus, not a } \\
\text { "scare" } \\
\text { " } \$ 25.6 \text { million for additional mental health } \\
\text { services, with a particular emphasis on providing } \\
\text { more culturally and linguistically appropriate } \\
\text { services, such as outreach to communities of } \\
\text { color, tribes, and vulnerable populations." } \\
\text { - "Outreach" implies that these communities } \\
\text { are disconnected, lack power in public } \\
\text { institutions and social safety nets }\end{array}$ & $\begin{array}{l}\frac{\text { evote-247-mil }}{\text { lion-in-federal }} \\
\text {-coronavirus- } \\
\text { aid-to-renter-r } \\
\text { elief-rural-hos } \\
\text { pitals-child-ca } \\
\underline{\text { re-and-more. }} \\
\underline{\text { html }}\end{array}$ \\
\hline $6 / 1$ & $\begin{array}{l}\text { Opinion: Amid } \\
\text { Pandemic, City } \\
\text { and Multnomah } \\
\text { County }\end{array}$ & $\begin{array}{l}\text { "Black and indigenous people are hardest hit. } \\
\text { LGBTQ+ people, immigrants and refugees, } \\
\text { veterans, those with disabilities and health } \\
\text { complications, children and elders also bear the } \\
\text { brunt of these inequities. With unemployment at } \\
\text { an all-time high and eviction moratoriums set to } \\
\text { soon expire, researchers predict that } \\
\text { homelessness will increase } 40-45 \% \text { by the } \\
\text { summer" }\end{array}$ & $\begin{array}{l}\frac{\text { https://www.o }}{\text { regonlive.co }} \\
\frac{\text { m/opinion/20 }}{20 / 06 / o p i n i o n} \\
\frac{\text {-amid-pande }}{\text { mic-city-and- }} \\
\text { multnomah-c } \\
\underline{\text { ounty-must-st }} \\
\text { ep-up-housin } \\
\text { g-facilities-for } \\
\underline{\text {-the-houseles }} \\
\underline{\text { s.html }}\end{array}$ \\
\hline $6 / 1$ & $\begin{array}{l}\text { Ron Herndon } \\
\text { Remembers } \\
\text { When Portland } \\
\text { Was Deeply } \\
\text { Racist, Like It } \\
\text { Was Yesterday }\end{array}$ & $\begin{array}{l}\text { "He isn't in the streets this week: He's } 74 \text { and all } \\
\text { too aware that he's vulnerable to COVID-19. But } \\
\text { he has remained vocal about everything: the } \\
\text { protests and looting; defunding the police; Gov. } \\
\text { Kate Brown's lackadaisical response to COVID } \\
\text { and people of color; the media's role in all of this; } \\
\text { and how the lack of any standards for child care } \\
\text { may be more racist than the lack of federal } \\
\text { guidelines on police use of force." }\end{array}$ & $\begin{array}{l}\frac{\text { https://www.w }}{\text { week.com/ne }} \\
\frac{\text { ws/2020/06/1 }}{\text { O/ron-herndo }} \\
\frac{\text { n-remembers }}{\text {-when-portlan }} \\
\frac{\text { d-was-deeply }}{\text {-racist-like-it- }} \\
\text { was-yesterda }\end{array}$ \\
\hline
\end{tabular}




\begin{tabular}{|c|c|c|c|}
\hline & & & $\mathrm{yl}$ \\
\hline $6 / 14$ & $\begin{array}{l}\text { Coronavirus } \\
\text { outbreaks } \\
\text { surges among } \\
\text { Oregon food } \\
\text { processors as } \\
\text { state scrambles } \\
\text { to react }\end{array}$ & $\begin{array}{l}\text { "State health authorities didn't issue a "playbook" } \\
\text { on how to respond to outbreaks at food } \\
\text { processing sites until early June, more than three } \\
\text { months after Oregon detected its first coronavirus } \\
\text { cases. They didn't send operational guidance to } \\
\text { all employers until the beginning of June, either." } \\
\text { "Fourteen of } 24 \text { active workplace outbreaks in } \\
\text { Oregon are at agricultural or food processing } \\
\text { facilities, according to data released by the state } \\
\text { this past week." } \\
\text { - Certain work has been established to be } \\
\text { connected to immigrant communities } \\
\text { "It has been evident from the beginning of the } \\
\text { pandemic that the food processing industry is } \\
\text { especially vulnerable to coronavirus outbreaks } \\
\text { among workers. The work is typically done } \\
\text { indoors, often in close quarters, in cool conditions } \\
\text { that favor the virus." } \\
\text { "Additionally, the industry's low-wage workers -- } \\
\text { many of them immigrants and migrants -- may not } \\
\text { have the clout to demand better working } \\
\text { conditions." } \\
\text { What would the "clout" look like? A license } \\
\text { to be recognized by labor and health } \\
\text { organizations? }\end{array}$ & $\begin{array}{l}\frac{\text { https://www.o }}{\text { regonlive.co }} \\
\frac{\text { m/coronaviru }}{\text { s/2020/06/cor }} \\
\frac{\text { onavirus-outb }}{\text { reaks-surge-a }} \\
\text { mong-oregon } \\
\text {-food-process } \\
\text { ors-as-state-s } \\
\underline{\text { crambles-to-r }} \\
\text { eact.html }\end{array}$ \\
\hline $6 / 17$ & $\begin{array}{l}\text { Oregon: Face } \\
\text { masks required } \\
\text { in tri-county } \\
\text { area }\end{array}$ & $\begin{array}{l}\text { "We know that front-line workers (many of whom } \\
\text { are BIPOC and low socio-economic) who directly } \\
\text { interact with the public are especially at-risk when } \\
\text { customers and clients don't wear face coverings," } \\
\text { the letter says, using an acronym for black, } \\
\text { indigenous or people of color. "More widespread } \\
\text { use of face coverings will help keep them safe. }\end{array}$ & $\begin{array}{l}\text { https://pampli } \\
\text { nmedia.com/r } \\
\underline{\text { c/62-news/47 }} \\
\underline{0663-380839} \\
\text {-oregon-face- } \\
\text { masks-requir } \\
\text { ed-indoors-in- } \\
\underline{\text { tri-county-are }} \\
\underline{\text { a }}\end{array}$ \\
\hline $6 / 18$ & $\begin{array}{l}\text { Oregon react to } \\
\text { supreme court } \\
\text { ruling on DACA }\end{array}$ & $\begin{array}{l}\text { "For now, those immigrants retain their protection } \\
\text { from deportation and their authorization to work in } \\
\text { the United States " }\end{array}$ & $\frac{\underline{\text { https://pampli }}}{\underline{\text { nmedia.com/ } / 9-n e w s / 47}}$ \\
\hline
\end{tabular}




\begin{tabular}{|c|c|c|c|}
\hline & & $\begin{array}{l}\text { "We were very happy to see this win. Woodburn } \\
\text { is home to hundreds of DACA recipients } \\
\text { (including) many who came through the doors of } \\
\text { the service center at PCUN for help with their } \\
\text { applications." } \\
\text { "We are very happy about the SCOTUS decision, } \\
\text { but this is an issue that is much bigger than } \\
\text { DACA," Arredondo said. "Until we have fair } \\
\text { immigration reform with a pathway towards } \\
\text { citizenship for the } 11 \text { million undocumented } \\
\text { essential workers, our work is far from done." } \\
\text { "Oregon is a "sanctuary state" and many of the } \\
\text { cities in the metro area are "sanctuary cities." The } \\
\text { non-legal term means a city, county or state that } \\
\text { will not hold a person solely for the sake of } \\
\text { federal immigration officials. " }\end{array}$ & $\begin{array}{l}\frac{0682-380869}{\text {-oregonians-r }} \\
\text { eact-to-supre } \\
\text { me-court-rulin } \\
\text { g-on-daca-pw } \\
\underline{\text { off }}\end{array}$ \\
\hline $6 / 19$ & $\begin{array}{l}\text { Trump says he } \\
\text { will renew effort } \\
\text { to end DACA } \\
\text { protections for } \\
\text { dreamers }\end{array}$ & $\begin{array}{l}\text { "Undeterred by this week's Supreme Court ruling, } \\
\text { President Donald Trump said Friday he will renew } \\
\text { his effort to end legal protections for hundreds of } \\
\text { thousands of immigrants brought to the United } \\
\text { States as children." } \\
\text { - A day later, the ruling above is unstable }\end{array}$ & $\begin{array}{l}\frac{\text { https://www.o }}{\text { regonlive.co }} \\
\frac{\text { m/nation/202 }}{\text { 0/06/trump-sa }} \\
\frac{\text { ys-he-will-ren }}{\text { ew-effort-to-e }} \\
\underline{\text { nd-daca-prot }} \\
\underline{\text { ections-for-dr }} \\
\underline{\text { eamers.html }}\end{array}$ \\
\hline $6 / 20$ & $\begin{array}{l}\text { Coronavirus } \\
\text { ravages Latino } \\
\text { communities in } \\
\text { the U.S. }\end{array}$ & $\begin{array}{l}\text { "As the coronavirus spreads deeper across } \\
\text { America, it's ravaging Latino communities from } \\
\text { the suburbs of the nation's capital to the farm } \\
\text { fields of Florida to the sprawling suburbs of } \\
\text { Phoenix and countless areas in between, } \\
\text { including hot spots in Oregon." } \\
\text { "The virus has amplified inequalities many } \\
\text { Latinos endure, including jobs that expose them } \\
\text { to others, tight living conditions, lack of health } \\
\text { insurance, mistrust of the medical system and a } \\
\text { greater incidence of preexisting health conditions } \\
\text { like diabetes. And many Latinos don't have the }\end{array}$ & $\begin{array}{l}\frac{\text { https://www.o }}{\text { regonlive.co }} \\
\underline{\text { m/coronaviru }} \\
\underline{\text { s/2020/06/cor }} \\
\underline{\text { onavirus-rava }} \\
\text { ges-latino-co } \\
\underline{\text { mmunities-in- }} \\
\underline{\text { us.html }}\end{array}$ \\
\hline
\end{tabular}




\begin{tabular}{|c|c|c|c|}
\hline & & $\begin{array}{l}\text { luxury of sheltering at home." } \\
\text { • Recurring issues } \\
\text { "The same disparities exist nationwide. In } \\
\text { Oregon, Latinos are disproportionately_affected. } \\
\text { Gov. Kate Brown loosened testing restrictions_to } \\
\text { allow people of color who are symptom free to get } \\
\text { tested for COVID-19 because of the disparities. } \\
\text { Workplace outbreaks in the state, such as in } \\
\text { Newport, have hit Latino workers especially hard. } \\
\text { Contact tracing is complicated_when workers, } \\
\text { such as some in Newport, speak languages } \\
\text { indigenous to Central America." } \\
\text { "The ZIP code with the most COVID-19 cases in } \\
\text { Maryland borders the nation's capital and is } \\
\text { majority Hispanic." } \\
\text { • A zip code can signal racial/ethnic } \\
\quad \text { segregation } \\
\text { "Lack of insurance, her immigration status and } \\
\text { misinformation about the pandemic kept her } \\
\text { home, but she finally went to the hospital and } \\
\text { tested positive for COVID-19." } \\
\text { ""I think that this pandemic has really highlighted } \\
\text { issues that have always plagued our community } \\
\text { and we've been fighting to overcome," said Dr. } \\
\text { Michelle LaRue, senior manager for health and } \\
\text { social services at CASA, an organization helping } \\
\text { Latinos in Maryland. "You know, labor safety } \\
\text { issues, language access issues, health insurance } \\
\text { and health care issues."” } \\
\text { - It becoming my thought that }\end{array}$ & \\
\hline $6 / 22$ & $\begin{array}{l}\text { Coronavirus } \\
\text { spike in } \\
\text { Multnomah } \\
\text { County Linked } \\
\text { to Spread } \\
\text { Among Friends, } \\
\text { Family, Officials } \\
\text { Say }\end{array}$ & $\begin{array}{l}\text { "Infections within immigrant and refugee } \\
\text { communities drove some portion of the spike, } \\
\text { officials said." } \\
\text { - Immigrant and Refugee communities } \\
\text { identified as those who are attributing to } \\
\text { covid numbers } \\
\text { "But county officials declined to quantify how } \\
\text { many of the nearly } 300 \text { new infections were } \\
\text { linked to so-called social clusters. - Nor would } \\
\text { they identify the specific immigrant and refugee } \\
\text { groups impacted, saying more information will be } \\
\text { released after officials speak with community }\end{array}$ & $\begin{array}{l}\frac{\text { https://www.o }}{\text { regonlive.co }} \\
\text { m/coronaviru } \\
\frac{\text { s/2020/06/cor }}{\text { onavirus-spik }} \\
\frac{\text { e-in-multnom }}{\text { ah-county-lin }} \\
\text { ked-to-spread } \\
\text {-among-frien } \\
\text { ds-family-offic } \\
\text { ials-say.html }\end{array}$ \\
\hline
\end{tabular}




\begin{tabular}{|c|c|c|c|}
\hline & & $\begin{array}{l}\text { leaders for at least a half-dozen populations." } \\
\text { "The continued spread among vulnerable } \\
\text { communities highlights the yawning gap of } \\
\text { infections within Multnomah County, where } \\
\text { people of color have accounted for nearly } 21 / 2 \\
\text { times more infections than whites over the past } \\
\text { seven weeks." } \\
\text { • Itching closer to the idea that COVID is a } \\
\quad \text { problem for particular identity groups } \\
\text { "Toevs said county officials are seeing an } \\
\text { increase in larger family settings, particularly } \\
\text { multigenerational households. There's particular } \\
\text { concern about increased infections in "a variety of } \\
\text { different immigrant communities." } \\
\text { "Toevs declined to identify which groups have } \\
\text { seen a recent spike in infections but said they are } \\
\text { among "seven or eight different distinct } \\
\text { immigrant, refugee and ethnic populations." } \\
\text { "County officials would prefer that impacted } \\
\text { community members first learn about infections } \\
\text { from "trusted partners," such as } \\
\text { community-based organizations, rather than the } \\
\text { mainstream media, she said. " } \\
\text { Elite media not connected to these } \\
\text { communities. And directed as such by } \\
\text { country officials } \\
\text { residents who live in mid-Multnomah County ZIP } \\
\text { codes that have consistently reported high cases, } \\
\text { officials said." } \\
\text { decades-old structural issues - including racism } \\
\text { and disparities in health care - that cannot } \\
\text { immediately be undone, she said." }\end{array}$ & \\
\hline $6 / 22$ & $\begin{array}{l}\text { As Cases Rises } \\
\text { in Multnomah } \\
\text { County, }\end{array}$ & $\begin{array}{l}\text { "There are seven or eight clusters of cases in } \\
\text { separate ethnic and immigrant communities that }\end{array}$ & 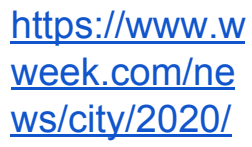 \\
\hline
\end{tabular}




\begin{tabular}{|c|c|c|c|}
\hline & $\begin{array}{l}\text { Officials Offer } \\
\text { Explanation: } \\
\text { Clusters in } \\
\text { Families }\end{array}$ & $\begin{array}{l}\text { officials are focused on. County officials did not } \\
\text { name which groups, but said they would release } \\
\text { more details after talking to different communities, } \\
\text { and cautioned that all ethnic groups are seeing } \\
\text { new cases." }\end{array}$ & $\begin{array}{l}\frac{06 / 22 / a s-c a s}{\text { es-rise-in-mul }} \\
\underline{\text { tnomah-count }} \\
\text { y-officials-offe } \\
\underline{\text { r-an-explanati }} \\
\underline{\text { on-clusters-in }} \\
\text {-families/ }\end{array}$ \\
\hline $6 / 22$ & $\begin{array}{l}\text { Washington } \\
\text { County offers } \\
\text { free mental } \\
\text { health service } \\
\text { amid pandemic }\end{array}$ & $\begin{array}{l}\text { "When a disaster hits, people rally to meet the } \\
\text { needs of the community's most vulnerable, said } \\
\text { Kristin Burke, Washington County's human } \\
\text { services division manager." } \\
\text { "Washington County officials partnered with the } \\
\text { Asian Health \& Services Center because the } \\
\text { psychological impacts of the pandemic have had } \\
\text { a particularly pronounced impact on members of } \\
\text { the Asian community. Many Asian Americans and } \\
\text { immigrants have reported instances of racism } \\
\text { since the coronavirus, which originated in } \\
\text { southern China, arrived in the United States." }\end{array}$ & $\begin{array}{l}\frac{\text { https://pampli }}{\text { nmedia.com/r }} \\
\frac{\text { c/62-news/47 }}{1127-381194} \\
\text {-washington- } \\
\text { county-offers- } \\
\text { free-mental-h } \\
\text { ealth-service- } \\
\text { amid-pandem } \\
\underline{\text { ic }}\end{array}$ \\
\hline $6 / 28$ & $\begin{array}{l}\text { Farmworker } \\
\text { advocates } \\
\text { worry Oregon's } \\
\text { protections } \\
\text { won't keep } \\
\text { laborers safe } \\
\text { from } \\
\text { coronavirus as } \\
\text { harvests ramp } \\
\text { up }\end{array}$ & $\begin{array}{l}\text { "Dr. Eva Galvez helps operate a mobile } \\
\text { healthcare clinic for migrant and seasonal } \\
\text { farmworkers in Oregon every year through the } \\
\text { Virginia Garcia Memorial Health Center in } \\
\text { Hillsboro. She has seen firsthand the one-room } \\
\text { cabins and cramped living spaces where many } \\
\text { farmworkers reside each summer during the peak } \\
\text { of the harvest season." } \\
\text { "“'l'm extremely concerned," said Galvez, a family } \\
\text { physician who works primarily with immigrant and } \\
\text { Latino populations. "We're already hearing about } \\
\text { massive outbreaks in agricultural settings in other } \\
\text { parts of the country and I think it will happen in } \\
\text { Oregon too. I want to be optimistic, but I'm really } \\
\text { worried.”" } \\
\text { "But the Oregon harvest season is just ramping } \\
\text { up, and many of the employer-provided dwellings } \\
\text { that house a large portion of the estimated } \\
160,000 \text { farmworkers and their families in Oregon }\end{array}$ & $\begin{array}{l}\frac{\text { https://www.o }}{\text { regonlive.co }} \\
\underline{\text { m/coronaviru }} \\
\underline{\text { s/2020/06/far }} \\
\text { mworker-adv } \\
\text { ocates-worry- } \\
\underline{\text { oregons-prot }} \\
\underline{\text { ections-wont- }} \\
\underline{\text { keep-laborers }} \\
\underline{\text {-safe-from-co }} \\
\underline{\text { ronavirus-as- }} \\
\underline{\text { harvest-seas }} \\
\underline{\text { on-ramps-up. }} \\
\underline{\text { html }}\end{array}$ \\
\hline
\end{tabular}




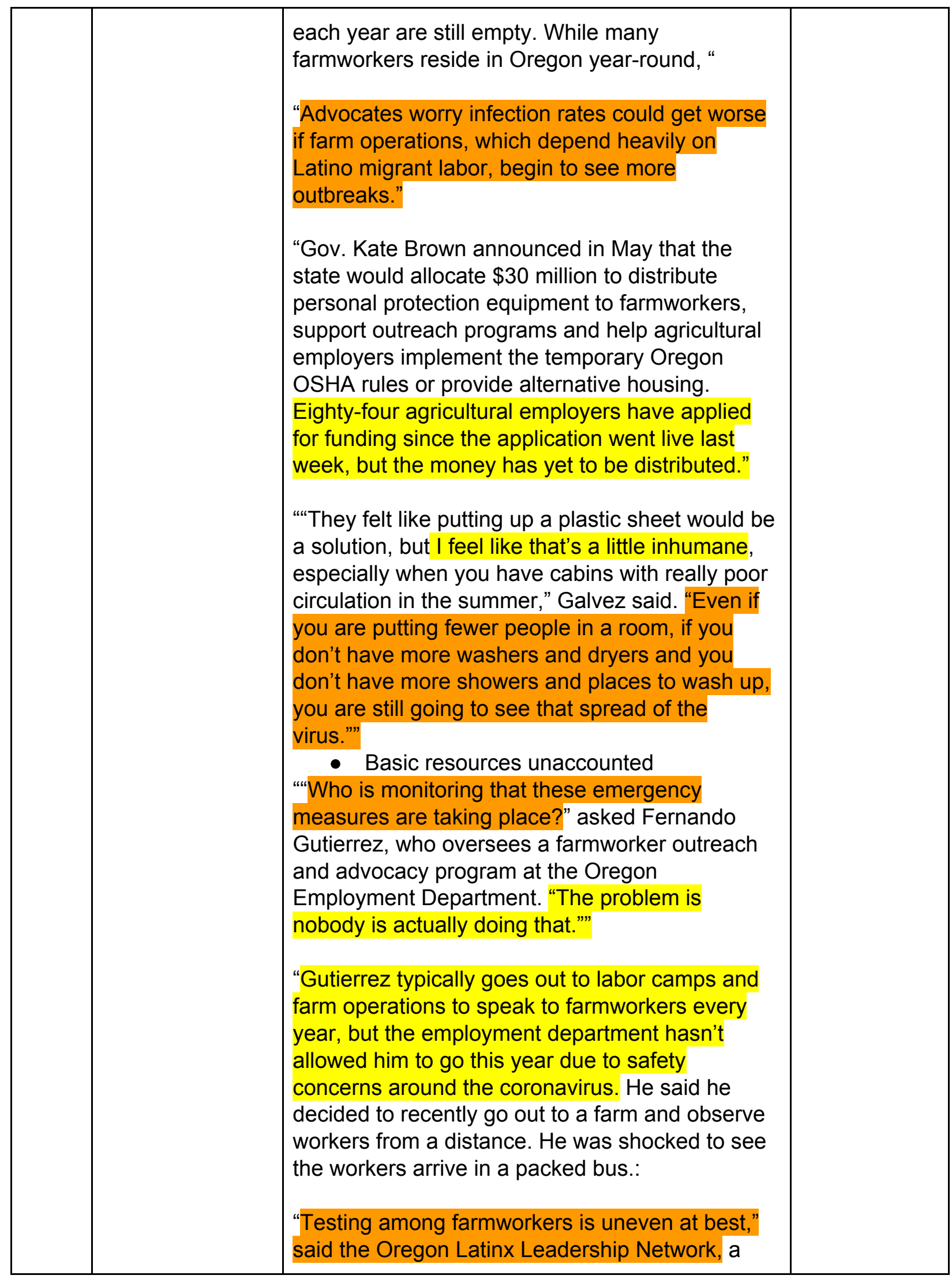




\begin{tabular}{|c|c|c|c|}
\hline & & $\begin{array}{l}\text { network of over } 70 \text { Latinx community-based } \\
\text { organizations, in a statement. "Given that there is } \\
\text { little chance of social distancing at the labor } \\
\text { housing where the farmworkers live, testing } \\
\text { should not be left up to chance. We want to see } \\
\text { farmworkers protected upon entry to the labor } \\
\text { housing and provided follow up serial testing."” } \\
\text { "But Galvez said she has found that farmworkers } \\
\text { are fearful that if they test positive they will be } \\
\text { unable to provide for their families or could lose } \\
\text { their jobs entirely. Many are undocumented and } \\
\text { worried about deportation, too." } \\
\text { "DeBess said the Oregon Health Authority has } \\
\text { been working with community organizations and } \\
\text { is providing resources for agricultural employers } \\
\text { and workers in a variety of languages on their } \\
\text { website. Galvez said that resources need to } \\
\text { continue to be translated into more languages, } \\
\text { including the indigenous Central American } \\
\text { languages that some farmworkers speak." } \\
\text { "Farmworkers can also access relief for lost } \\
\text { wages through the Oregon Worker Relief Fund, } \\
\text { which helps those disqualified from receiving } \\
\text { unemployment or stimulus benefits due to their } \\
\text { immigration status. } \\
\text { But advocates say that many farmworkers aren't } \\
\text { aware of these benefits, and that they need } \\
\text { additional protections." } \\
\quad \text { relief fund. With all information already } \\
\text { slowed by disconnected services, the } \\
\text { Oregon Worker Relief Fund is another. } \\
\quad \text { Elite Media, and Government institutions } \\
\text { have proven their distance and } \\
\text { communillingness to truly reach out to these }\end{array}$ & \\
\hline $6 / 30$ & $\begin{array}{l}\text { As coronavirus } \\
\text { cases rise } \\
\text { among }\end{array}$ & $\begin{array}{l}\text { "Multnomah County health officials acknowledged } \\
\text { Tuesday that they are still working to rebuild } \\
\text { relationships with refugee and immigrant }\end{array}$ & 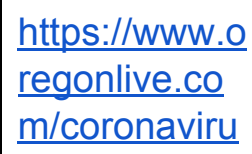 \\
\hline
\end{tabular}




\begin{tabular}{|c|c|c|c|}
\hline & $\begin{array}{l}\text { immigrant and } \\
\text { refugee groups, } \\
\text { Multnomah } \\
\text { County works } \\
\text { to rebuild } \\
\text { relationships }\end{array}$ & $\begin{array}{l}\text { community leaders to try to mitigate the spread of } \\
\text { COVID-19." } \\
\text { "People of color continue to be disproportionately } \\
\text { affected by COVID-19 in Multnomah County, and } \\
\text { public health officials first said earlier in June that } \\
\text { they were concerned about recent upticks of } \\
\text { cases in immigrant and refugee groups." } \\
\text { "Multnomah County partnered with a number of } \\
\text { organizations to translate information and to try to } \\
\text { track the spread of the virus. But much of that } \\
\text { work had to start from the ground up. " } \\
\text { "-the same type of relationship building during the } \\
\text { H1N1 pandemic a decade ago, but a lack of } \\
\text { funding meant the relationships weren't } \\
\text { sustained." } \\
\text { "Vines said the pandemic is a "renewed lesson" } \\
\text { about the importance of ongoing relationships } \\
\text { with refugee and immigrant community leaders." } \\
\text { there to begin with?? } \\
\text { "Multnomah County has seen growing cases in } \\
\text { other immigrant populations, specifically within } \\
\text { African and South Asian refugee groups, Toevs } \\
\text { said." }\end{array}$ & $\begin{array}{l}\frac{\text { s/2020/06/as- }}{\text { coronavirus-c }} \\
\underline{\text { ases-rise-am }} \\
\underline{\text { ong-immigran }} \\
\underline{\text { t-and-refugee }} \\
\text {-groups-multn } \\
\text { omah-county- } \\
\text { works-to-rebu } \\
\text { ild-relationshi } \\
\text { ps.html }\end{array}$ \\
\hline 07/01 & It's & "Som Subedi resettled in Portland as a refugee & https://www.o \\
\hline
\end{tabular}




\begin{tabular}{|c|c|c|}
\hline $\begin{array}{l}\text { retraumatizing } \\
\text { kind of } \\
\text { experience:' } \\
\text { How COVID-19 } \\
\text { Is affecting } \\
\text { refugee } \\
\text { communities in } \\
\text { Multnomah }\end{array}$ & 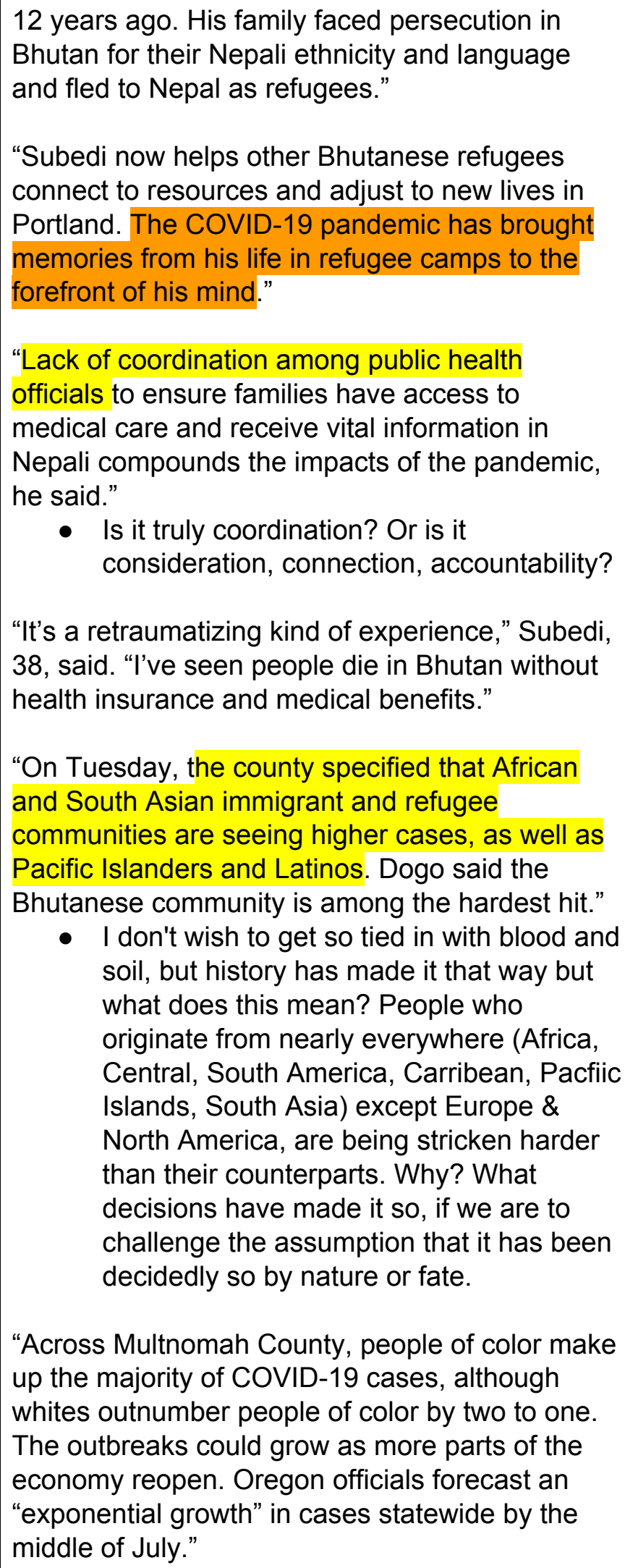 & $\begin{array}{l}\frac{\text { regonlive.co }}{\text { m/coronaviru }} \\
\underline{\text { s/2020/07/its- }} \\
\frac{\text { a-retraumatizi }}{\text { ng-kind-of-ex }} \\
\text { perience-how } \\
\underline{\text {-covid-19-is-a }} \\
\underline{\text { ffecting-refug }} \\
\underline{\text { ee-communiti }} \\
\underline{\text { es-in-multno }} \\
\underline{\text { mah-county.h }} \\
\underline{\text { tml }}\end{array}$ \\
\hline
\end{tabular}




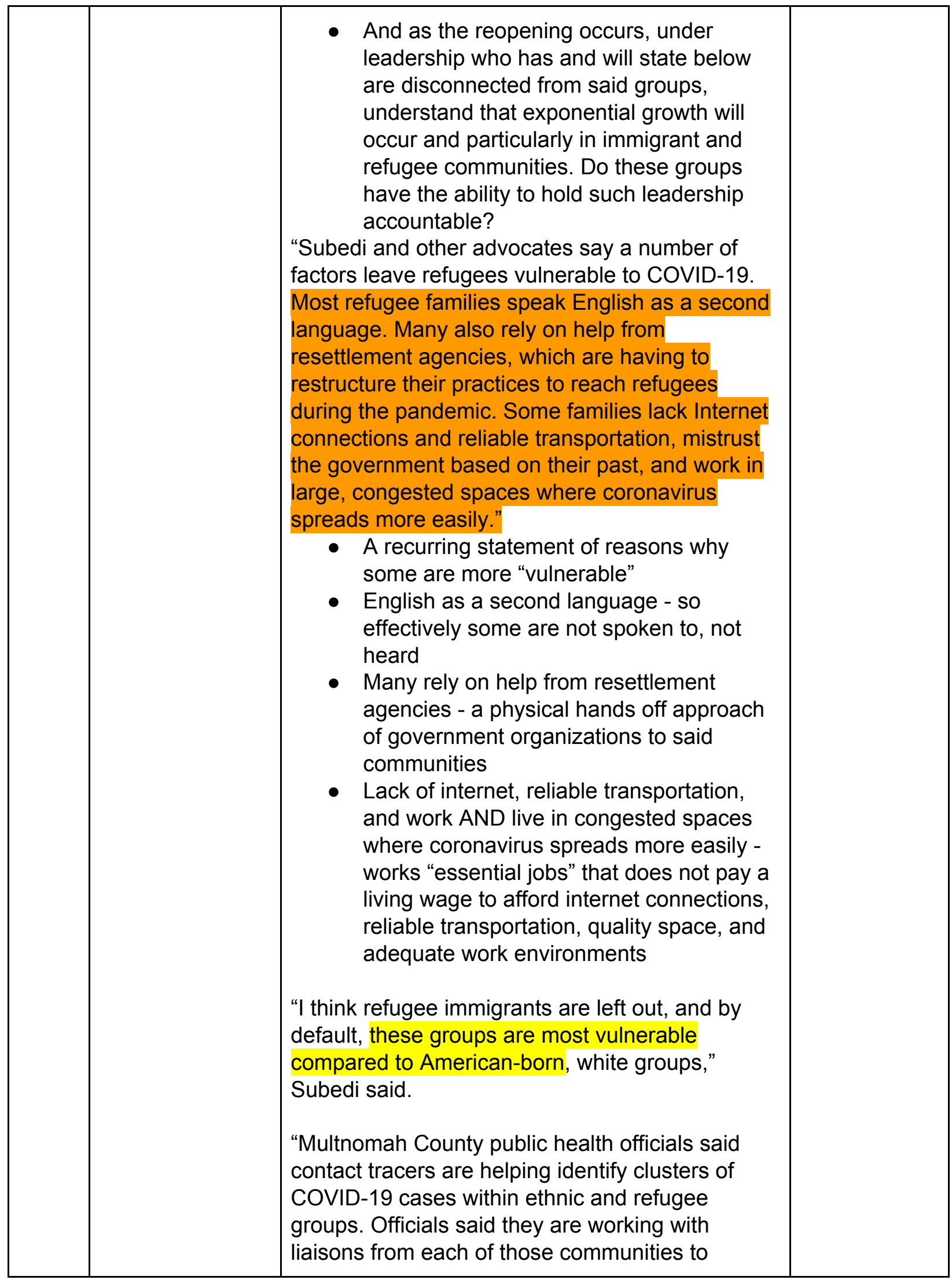




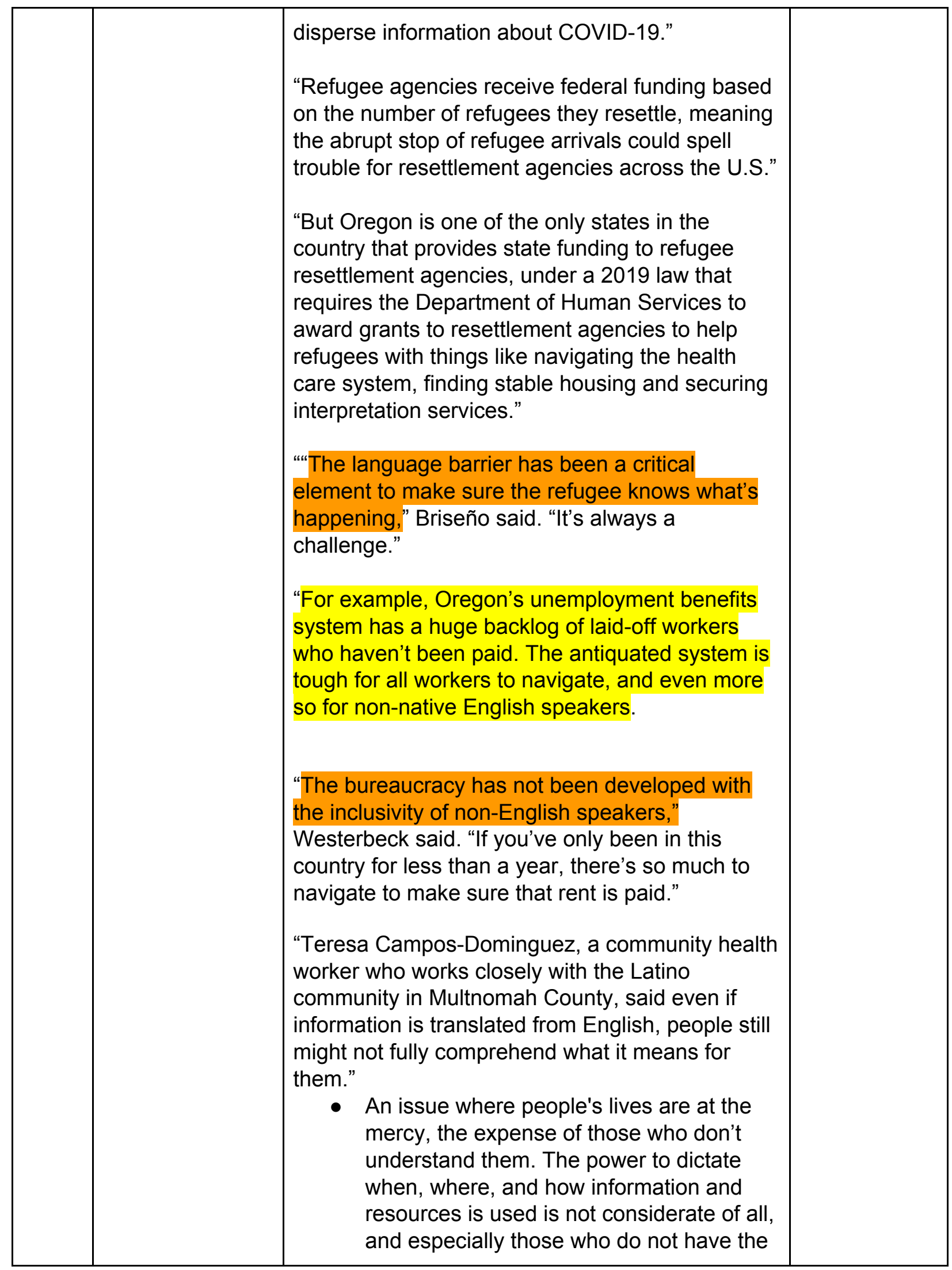




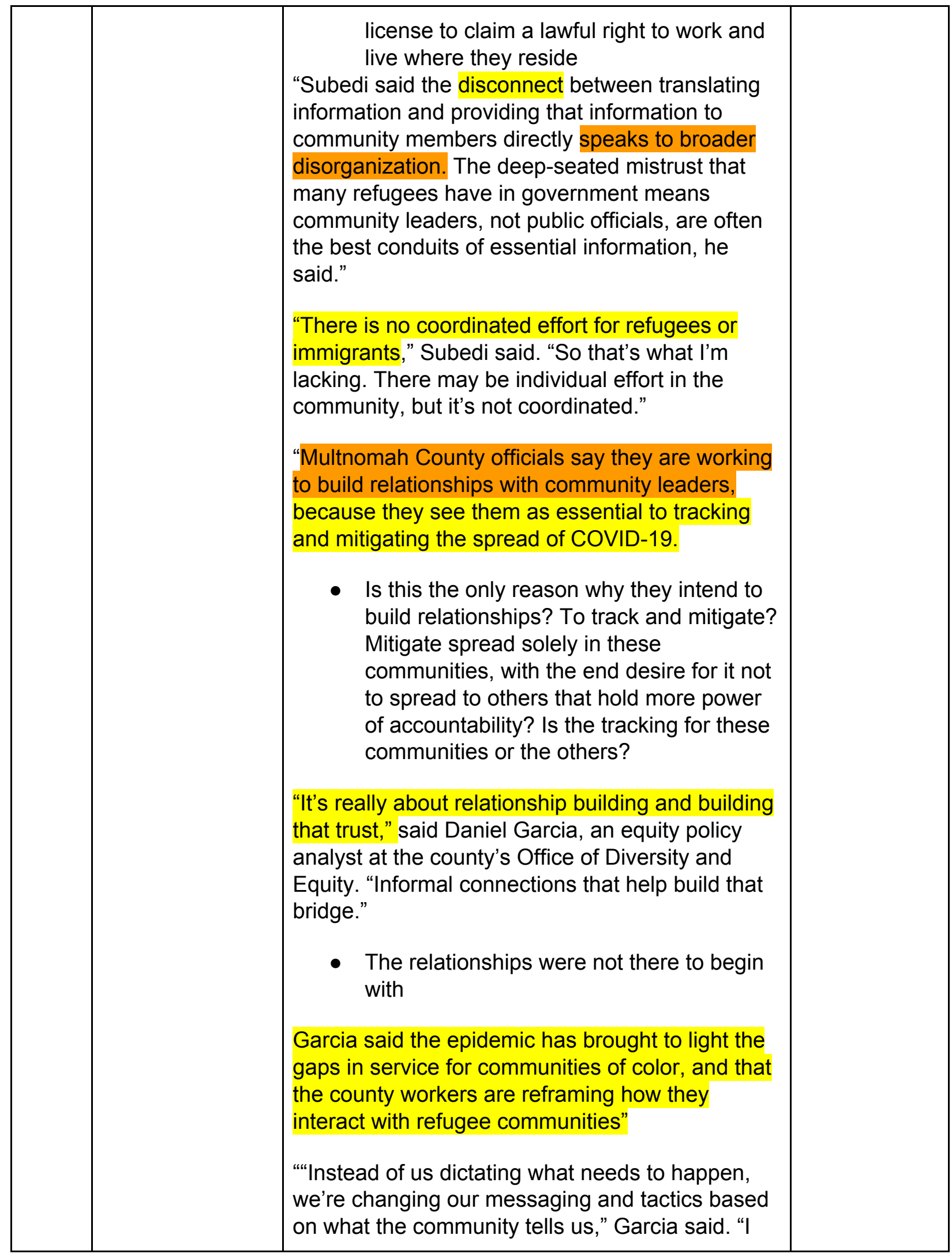




\begin{tabular}{|l|l|l|l|}
\hline & & $\begin{array}{l}\text { think that's where the county is learning to listen } \\
\text { to the community.” }\end{array}$ & \\
\hline & & & \\
\hline & & & \\
\hline & & & \\
\hline
\end{tabular}

